\title{
18. TURBIDITES, REDBEDS, SEDIMENTARY STRUCTURES, AND TRACE FOSSILS OBSERVED IN DSDP LEG 38 CORES AND THE SEDIMENTARY HISTORY OF THE NORWEGIAN-GREENLAND SEA
}

\author{
Tor H. Nilsen, U.S. Geological Survey, Menlo Park, California \\ With a Contribution on Redbeds by \\ Dennis R. Kerr, U.S. Geological Survey, Menlo Park, California
}

\begin{abstract}
The sedimentary history of the Norwegian-Greenland Sea is typical of rifted-margin ocean basins; it is marked by stratigraphic sequences that (1) were deposited in deeper water through time, as oceanic crust subsided away from the active spreading ridge, and (2) become finer grained and more biogenic through time, as the continental source areas moved farther away from the active spreading ridge during widening of the ocean basin. Nonmarine redbeds above subaerially weathered basalt form the base of the oldest sequences, formed when rifting of the single continent began. Turbidites were subsequently deposited as the rift widened, deepened, and became oceanic. Hemipelagic mudstones were deposited with further widening, and then biogenic calcareous and siliceous oozes were deposited as the influence of the distant continental margins on sedimentation diminished. Finally, ice-rafted glacial deposits blanketed the entire sea floor and all older deposits; the glacial deposits directly overlie newly created Plio-Pleistocene ocean floor near the active spreading ridge. A great variety of sedimentary structures, trace fossils, and related features are found within these stratigraphic sequences, which are complicated by the irregular tectonic history of the Norwegian-Greenland Sea.
\end{abstract}

\section{INTRODUCTION}

A great variety of both primary and secondary sedimentary structures, trace fossils, and related features were observed in cores from DSDP Leg 38 in the Norwegian-Greenland Sea (Figure 1). The purpose of this paper is to illustrate and discuss the various features observed, relate them to sedimentary processes, and consider the regional significance of these features. General references to the occurrence of some features in cores can be found in the paper by White (this volume, see especially fig. 20); however, a more detailed description, particularly with regard to processes responsible for formation of the various structures, will be found herein. In this paper, the term "glacial" refers to the age of generally undated sediments deposited by various glacial-related processes, presumably during the Pliocene and Pleistocene.

The sedimentary structures and related features are divided into three categories: (1) primary sedimentary structures such as cross-stratification, parallel stratification, formed at the time of deposition by currents and other sedimentation processes; (2) secondary sedimentary structures such as dish structures, concretions, formed after deposition, but generally before lithification of the sediments by slumping, dewatering, migration of interstitial water, and other processes; and (3) biogenic structures, primarily trace fossils, formed by burrowing and boring organisms. Two special types of sedimentary sequences, turbidites, formed by submarine processes, and redbeds, formed by alternating subaerial processes of sedimentation and weathering, are discussed in separate sections.

It must be emphasized that observations of the sedimentary structures and features are generally limited to what can be seen on the surface of the split cores, or a width of approximately $6 \mathrm{~cm}$. The lateral extent and distribution of the structures is generally not known, and stratification surfaces normally cannot be examined. These limitations, plus the fact that most cores suffer some deformation as a result of the coring process, from complete liquefaction to various types of fracturing, restrict the extent of classification, interpretation, and observation possible. The amount of coring deformation is particularly great in the upper 100-200 meters of each core; as a result, sedimentary structures are generally obscure and poorly preserved in Pliocene, Pleistocene, and Holocene sections.

The reader is referred to the sources listed in the references for more detailed discussions and illustrations of various sedimentary structures and features.

\section{PRIMARY SEDIMENTARY STRUCTURES AND FEATURES}

\section{Massive Bedding}

Massive, structureless bedding characterizes the great majority of sedimentary sequences observed in 

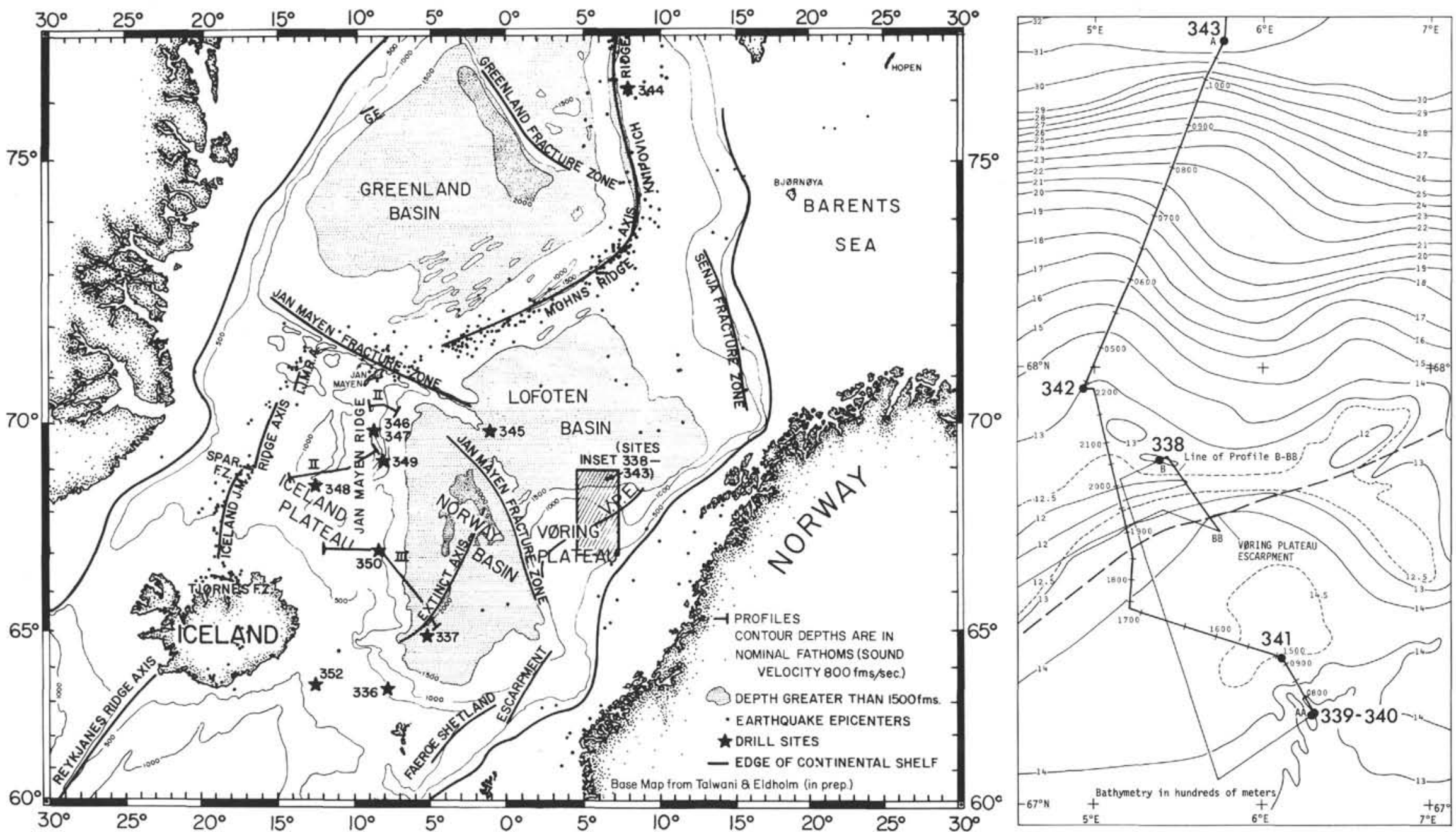

Figure 1. Location of Leg 38 drilling sites, and bathymetry and structure of the Norwegian-Greenland Sea. (Note: Site 351 was occupied but was not drilled. Its location has not been shown on this map.) The inset map shows the track of Glomar Challenger between Holes 338 and 343 on the Voring Plateau. Also shown are position of Voring Plateau Escarpment, and corrected bathymetry of the area, in hundreds of meters, constructed principally from records taken by $R / V$ Vema of Lamont-Doherty Geological Observatory, supplemented by Glomar Challenger data. 
Leg 38 cores, particularly thick sequences of pelagic clay, biogenic siliceous and calcareous sediments, and transitional siliceous and calcareous sediments (see White, this volume). These sediments accumulate largely as a result of particle-by-particle settling of finegrained terrigenous, volcanic, and biogenic material through the water column in the absence of strong bottom current activity. These sedimentary sequences may contain pseudoparallel stratification (see below), various types of trace fossils and bioturbation, as well as sporadic turbidite or volcanic ash interbeds. Contacts with other sedimentary units may be abrupt or gradual, depending upon whether other units represent a gradual change in type of pelagic or hemipelagic sedimentation or an abrupt change to turbiditic or volcanic sedimentation.

Sequences of virtually massive, internally structureless sediments are common in every hole, with stratification sometimes lacking in units as thick as several hundred meters (see, for example, Hole 341, Core 7-1 to Core $21-3$, an interval of approximately 200 $\mathrm{m}$ of massive lithologically uniform calcareous mud). Primary or secondary sedimentary structures may be present in these sediments, but extensive X-radiography would be required for their detection and study.

\section{Graded Bedding}

Graded bedding is characteristic of thick Paleogene turbidite sequences as well as some volcanic ash units; it has also been observed locally in scattered beds within "glacial" and Pleistocene sequences. In the thick turbidite sequences, it is indicative of the sorting processes that took place within turbidity currents during single depositional events; these currents flowed downslope along the submarine floor, eroding previously deposited sediments, and formed Bouma (1962) sequences. In the volcanic ash units and possibly in the "glacial" units, the grading probably results from selective settling of larger and heavier particles through a water column in which some currents were active, the former from volcanic eruptions and the latter probably from floods of glacial meltwater near continental margins or other land areas. The sediment-laden floodwaters probably entered the ocean as turbulent overflows or interflows, rather than as bottom flows, and formed beds without erosive bases and without Bouma (1962) sequences.

Graded bedding associated with thick lower and middle Tertiary turbidite sequences is present in 34312-1, 2, and 3 (lower Eocene); 345-21-2 to 345-30-5 (Oligocene-Eocene[?]); $346-15-2$ and 3 and $346-18-1$ to 346-20-1 (Eocene); 349-10-1 to 349-13-6 (upper Eocene); and $350-10-1$ to 350-13-2 (upper Eocene to Oligocene). In thinner beds, grading is very pronounced and regular (Figure 2); in thicker and coarser grained beds, coarse-tail grading, wherein only the coarsest clasts are graded, with the grain size of fine-grained matrix material remaining relatively uniform, is commonly present. The top contacts of the coarser and thicker graded beds may be represented by an abrupt rather than transitional change to mudstone or claystone. Locally, reverse grading may be present in the basal few centimeters of turbidite units, particularly some of the thicker units.

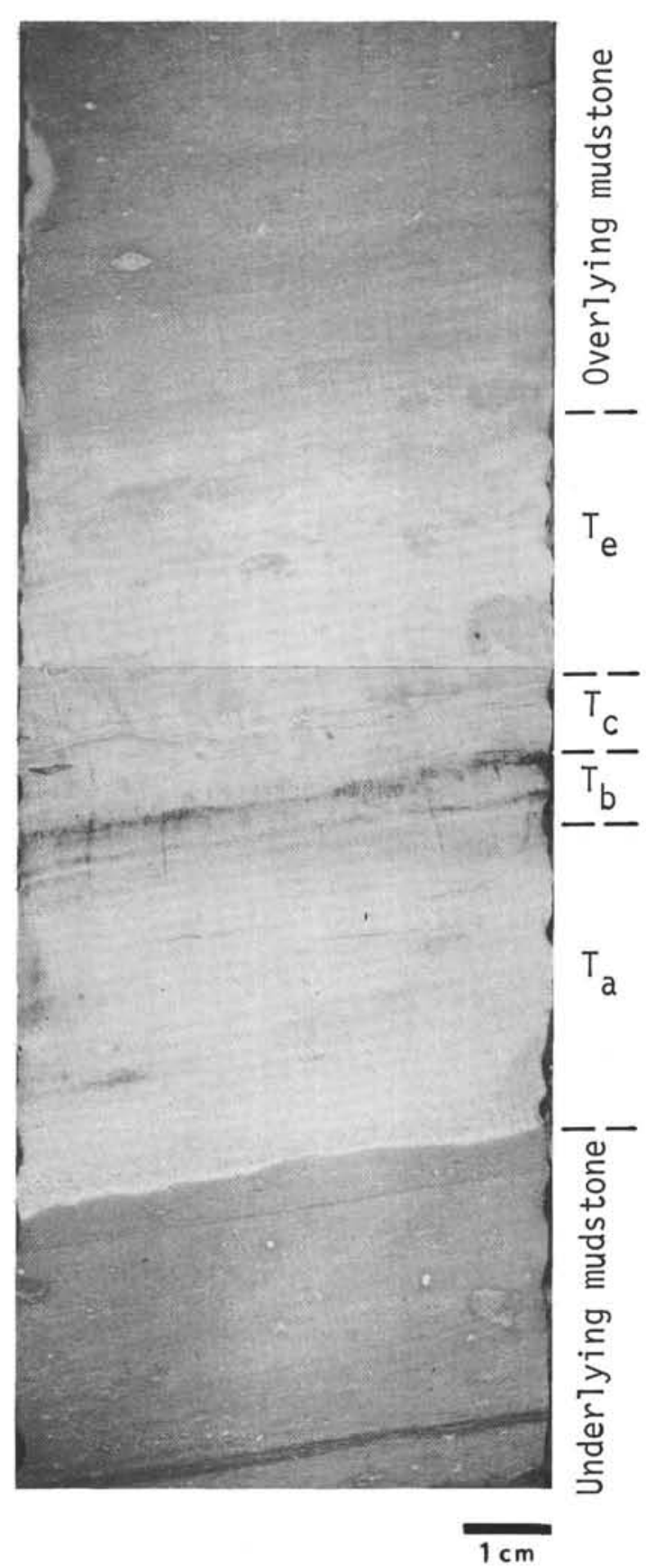

Figure 2. Well-graded calcareous Oligocene turbidite layer, 345-21-2, $74 \mathrm{~cm}$ (base of layer). $T_{a b c e}$ sequence contains, in ascending order, massive $T_{a}$ sandstone, parallel stratified $T_{b}$ sandstone, thin low-angle cross-stratified $T_{c}$ sandstone, and $T_{e}$ mudstone. Note scoured basal contact and worm tubes in underlying and overlying mudstone.

Graded volcanic ash units are present in 336-9-4; $340-4-3,105-110 \mathrm{~cm} ; 345-19-1,95-97 \mathrm{~cm}$ and 114-117 $\mathrm{cm}$; and $345-18-1,142-143 \mathrm{~cm}$. Any other ash units may be graded, but are too extensively deformed by coring to permit recognition of this feature. Graded bedding in "glacial" sediments was observed in 336-9-4 and 5; 341- 
20-6 and 341-21-1 to $6 ; 342-1-4,40-70 \mathrm{~cm}$ and 342-1-6, $30-80 \mathrm{~cm} ; 344-11-1,93-95 \mathrm{~cm}$ and 344-13-1, $135 \mathrm{~cm}$; and in Miocene or Pliocene sediments of possible glacial origin in 344-30-1, 90-105 cm, 344-31-1, 83-90 cm, and $344-33-1,2$, and 3 . These occurrences are generally limited to single isolated beds or pairs of beds rather than a thicker sequence of layered turbidites.

\section{Parallel Lamination}

Parallel lamination is common in numerous turbidite sequences, both in the Bouma $T_{b}$ interval, where it is developed generally in fine- to coarse-grained sandstone, and in the Bouma $T_{d}$ interval, where it is developed in fine-grained sandstone to siltstone. Parallel lamination is a particularly common feature in the lower Eocene and Oligocene turbidites of Sites 343, $345,346,349$, and 350 (Figure 3).

\section{Cross-Stratification}

Small-scale cross-strata, probably formed by migrating current ripples, are relatively abundant in Leg 38 cores. They characterize turbidite sequences, where they comprise the Bouma $T_{c}$ interval. Large-scale cross-strata (amplitudes greater than $5 \mathrm{~cm}$ ) were not recognized in any cores, indicating that larger features such as dunes and megaripples, which are most characteristic of fluvial, deltaic, and shallow marine sediments, were never formed in the depositional environments of Leg 38 sediments. It is possible, however, that the narrowness of the cores in some places may have prevented distinction of large-scale cross-strata from parallel strata.

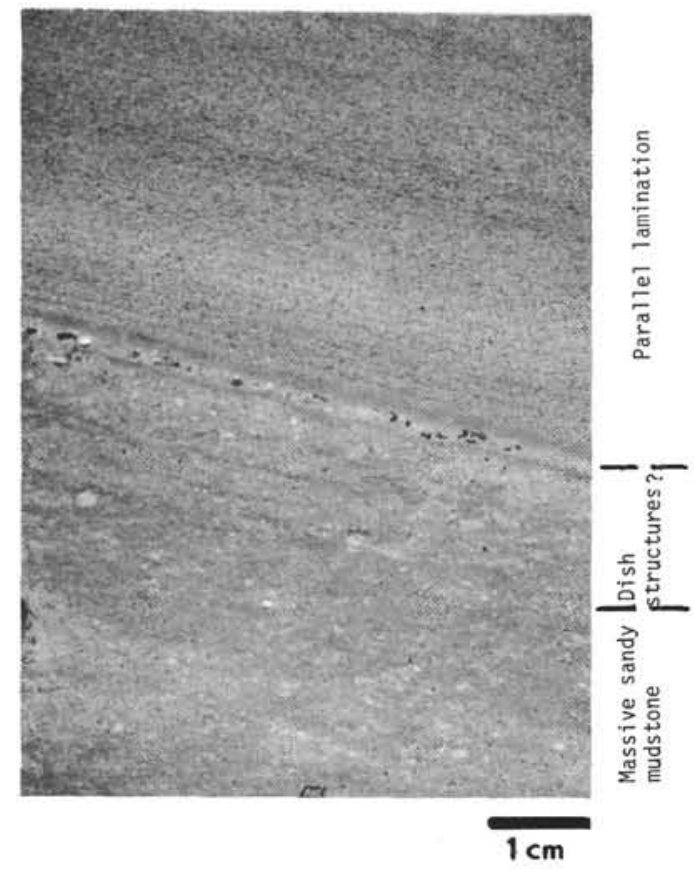

Figure 3. Parallel laminated Eocene(?) sandstone, probably Bouma $T_{b}$ sequence, developed over massive, ungraded pebbly and sandy mudstone. Contact between units at 345-30-5, $32 \mathrm{~cm}$; note partial development of dish structures in massive unit directly below laminated unit.
Small-scale cross-strata are present in Paleogene turbidite sequences only at 343-12-2 (lower Eocene), 34522-5 to 345-30-5 (Oligocene-Eocene[?]), and 349-10-2 to 349-11-5 (upper Eocene). Small-scale cross-strata were also noted in lower Eocene calcareous mud at 343-16-1, $125-140 \mathrm{~cm}$; this sedimentary unit is located between two basalts, however, and could not be definitely identified as being of turbidite origin. The small-scale crossstrata are developed primarily in fine-grained sandstone and siltstone. Figure 4 shows a crossstratified $T_{c}$ unit in a turbidite layer. Figure 5 shows a cross-stratified isolated siltstone layer approximately $0.5 \mathrm{~cm}$ thick; although not clearly of turbidite origin, it occurs in a sequence that contains other turbidites and may represent a thin Bouma $T_{\text {ce }}$ unit.

In some turbidites, the Bouma $T_{c}$ interval is very thick and consists of a vertically stacked series of smallscale ripple markings that locally may resemble rippledrift lamination. Examples of such thick $T_{c}$ intervals can be observed in Samples 345-28-0, 15-45 cm and 349-11-2, 5-35 cm (Figure 6).

Small-scale cross-strata were also questionably identified in "glacial" sediments at 336-9-5, in a group of several isolated graded layers.

\section{Convolute Lamination}

Convolute lamination is present in several turbidite sequences, generally developing as a result of synsedimentary deformation of current ripple markings during deposition of the $T_{c}$ unit of the Bouma sequence. Changing current velocities, drag of the current passing over the depositional interface, as well as other factors, may cause the sediment or part of the sediment to flow hydroplastically and develop a convoluted form.

An example of convolute lamination is shown in Figure 7, developed in the upper Eocene turbidite sequence of Site 349. It is present at the top of the $T_{c}$ interval of a 40-cm-thick Bouma $T_{\text {bede }}$ sequence that rests on top of an $80-\mathrm{cm}$-thick pebbly mudstone unit. The basal $10 \mathrm{~cm}$ of the bed consists of alternating parallel laminated and low-inclination angle cross-laminated sandy mudstone. This is overlain by the convoluted interval, about $8 \mathrm{~cm}$ thick, which is in turn overlain by about $12 \mathrm{~cm}$ of parallel interlaminated siltstone and mudstone (Bouma $T_{d}$ interval) and about $10 \mathrm{~cm}$ of massive claystone (Bouma $T_{e}$ interval). Other examples of convolute lamination were observed in thick turbidite sequences at $344-31-3,0-45 \mathrm{~cm} ; 345-28-5,0-10$ $\mathrm{cm}$; and $349-10-3,130-140 \mathrm{~cm}$. In 336-9-5, convolute lamination may be present within some thin, isolated graded layers of "glacial" age; however, the sediment is intensely deformed by coring, and the structure could not be positively identified.

\section{Unconformities and Diastems}

Several unconformities and diastems were observed in sedimentary sequences from Leg 38 cores. Those in younger Pliocene to recent sediments were genera-ly deformed by coring, and thus not clearly observable. However, some deeper and older breaks were clearly observed, particularly several marked by conglomeratic accumulations on the surface of unconformity and by angular discordances in attitude of strata above and below the surface. Minor unconformities, of course, are 


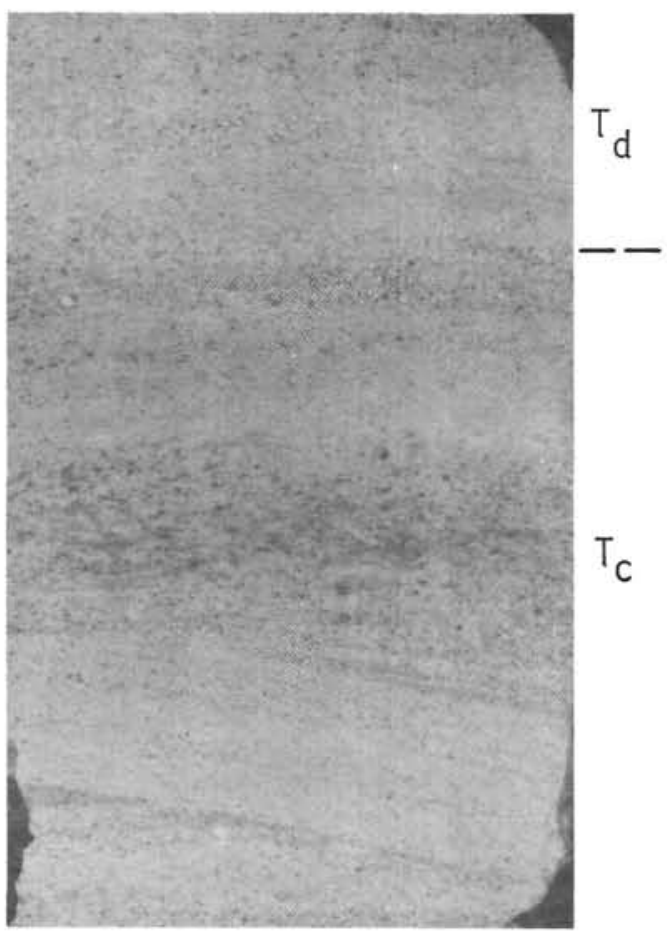

Figure 4. Cross-stratified calcareous sandstone near base of 30-cm-thick upper Eocene turbidite layers, 349-10-2, 55-60 cm, $\times 2$. The complete turbidite layer consists of a lower 7-mm-thick parallel-laminated Bouma T Unit, $9 \mathrm{~cm}$ of cross-stratified $(19-2,50-59 \mathrm{~cm})$ and $8 \mathrm{~cm}$ of convolute laminated (see Figure 7) $T_{c}$ sandstone, $11 \mathrm{~cm}$ of parallel laminated $T_{d}$ siltstone, and a topmost $9 \mathrm{~cm}$ of $T_{e}$ massive mudstone. Scale $1 \mathrm{~cm}$ on photo $=0.5 \mathrm{~cm}$ of core.

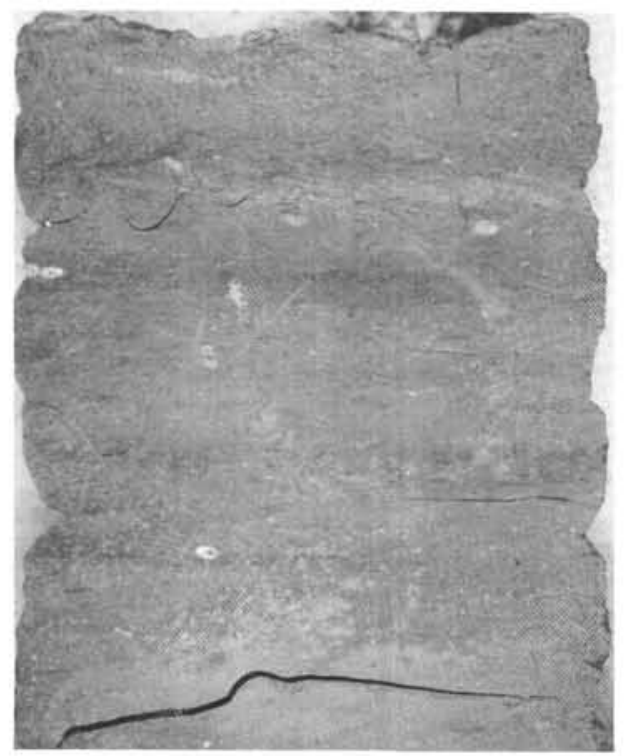

A also present at the base of most turbidite deposits; however, these will not be considered herein.

A prominent angular unconformity is present within a thick sequence of upper Eocene mudstone and sandy mudstone with scattered thin turbidite and ash horizons at $345-23-2,70 \mathrm{~cm}$. An angular discordance of approximately $20^{\circ}$ marks the contact, and also present is an intraformational conglomerate-breccia containing dolomitized(?) clasts that are partly bioturbated and as long as $2 \mathrm{~cm}$ (Figure 8). The bioturbated mudstone above and below the unconformity contains pseudoparallel lamination (see later section) and prominent normal faults, possibly of synsedimentary origin, but more likely caused by drilling deformation.

Another prominent unconformity is present deeper within the same upper Eocene(?) terrigenous sequence at $345-25-3,95 \mathrm{~cm}$. Here two mudstones are in contact, the upper one of darker color and thoroughly bioturbated, the lower one less bioturbated and containing scattered mudstone-claystone clasts near its top (Figure 9). The surface of unconformity makes about a $25^{\circ}$ angle with the overlying pseudoparallel stratification and has a visible relief of about $1.5 \mathrm{~cm}$.

These angular unconformities suggest tectonism penecontemporaneous with sedimentation, such that previous deposits were tilted and eroded prior to renewed sedimentation. There is no indication of an extensive gap in the sedimentary record at Site 345 , and thus the unconformities are minor ones. The significance of the tectonism, however, is difficult to evaluate without additional data from the region of Site 345 ; it does suggest, at the least, continued subaqueous slumping and tilting of sediments along a tectonically active depositional site.

Other prominent unconformities in turbidite sequences, of less importance because they are not angular in nature, can be seen at 349-10-2, $137 \mathrm{~cm}$, where a pebbly mudstone truncates an underlying mudstone along a surface inclined at approximately

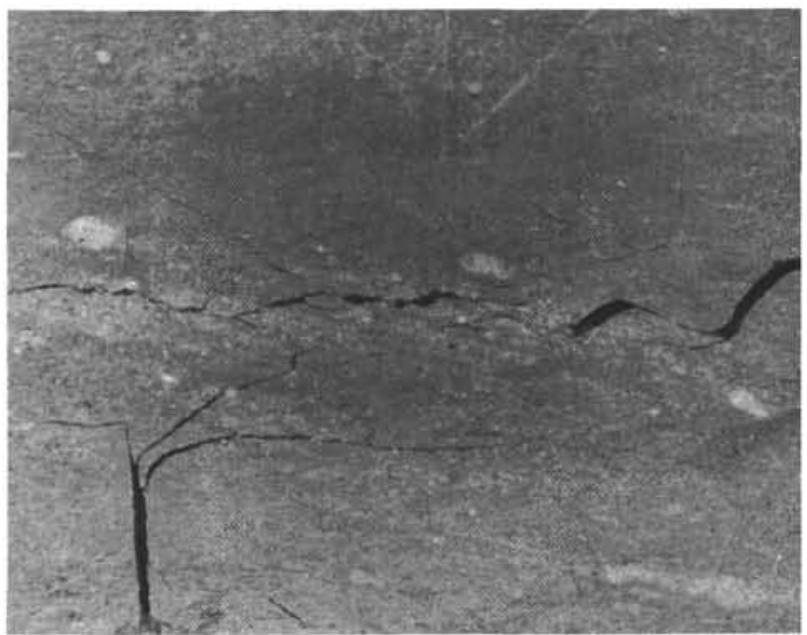

B

Figure 5. Small-scale cross-strata developed in thin siltstone within bioturbated mudstone sequence, 345-22$5,136 \mathrm{~cm}$. (a) true scale; (b) $1 \mathrm{~cm}$ on photo $=0.33 \mathrm{~cm}$ on core. Note hollow worm tubes in mudstone below cross-stratified layer. 


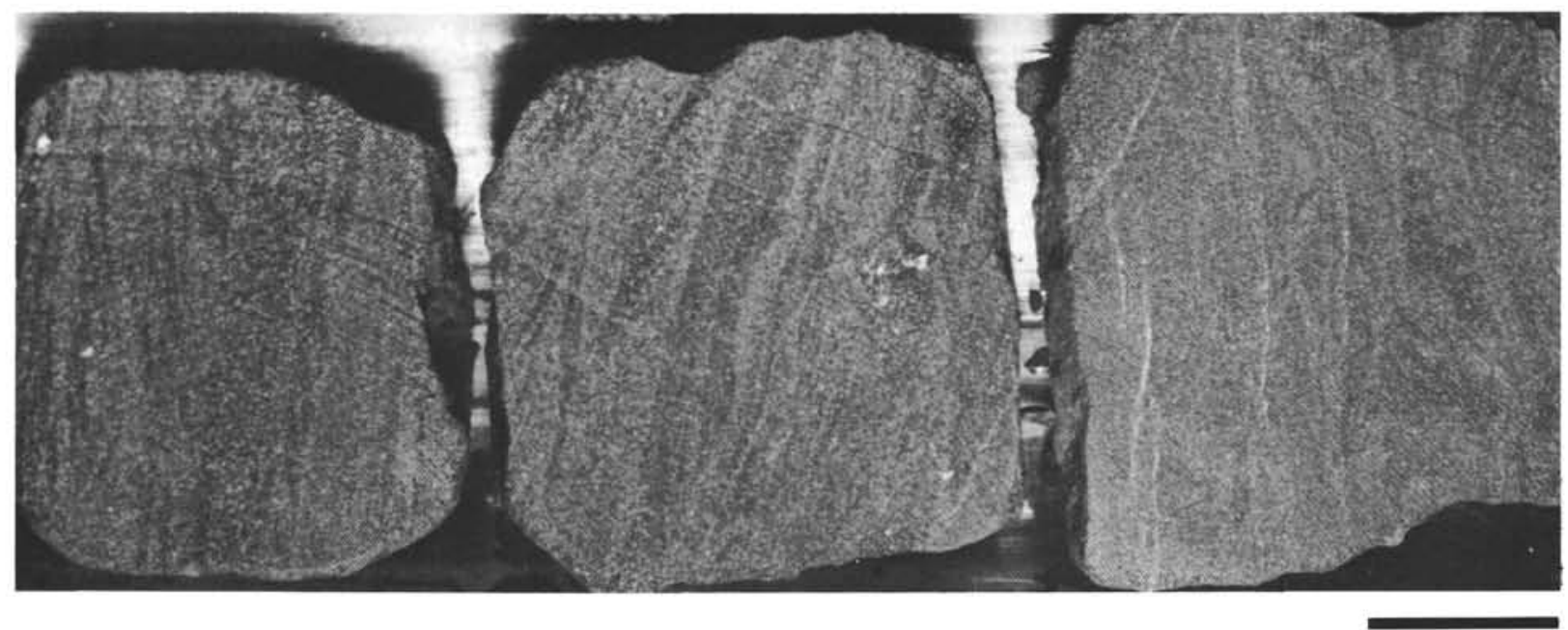

$2 \mathrm{~cm}$

Figure 6. Thick cross-stratified $T_{e}$ interval in Bouma $T_{b c e}$ sequence, upper Eocene turbidite, 349-11-2, 6-21 cm.

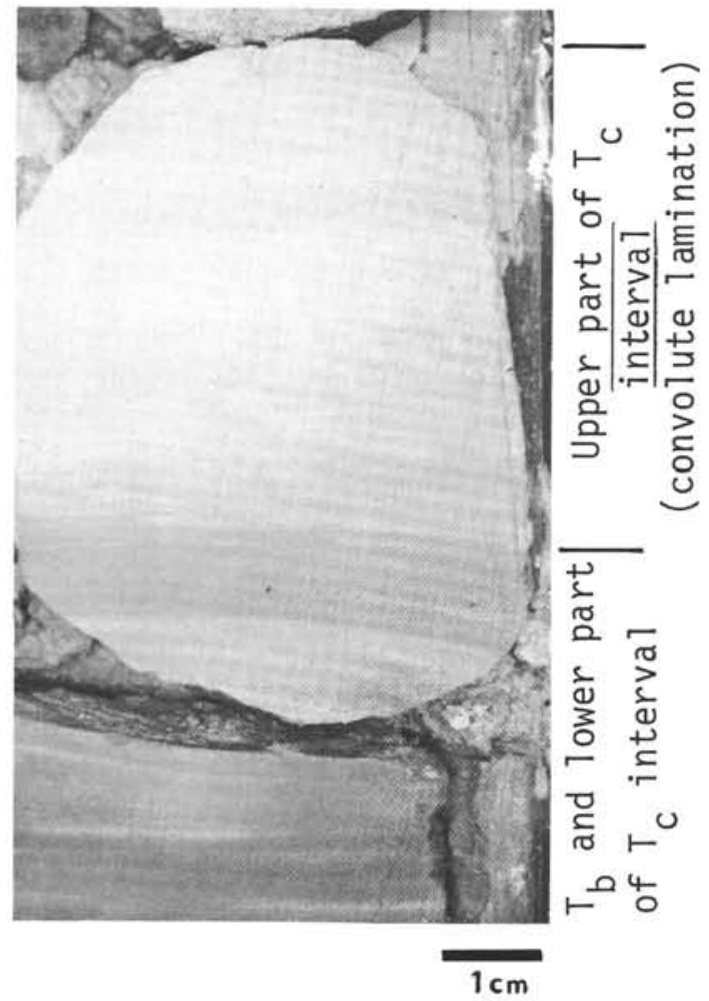

Figure 7. Convolute lamination in Bouma $T_{c}$ interval of upper Eocene turbidite sequence, 349-10-2, $42-50 \mathrm{~cm}$. Scale: $1 \mathrm{~cm}$ on photo $=$ $1 \mathrm{~cm}$ of core.

$20^{\circ}$; at $349-10-3,28 \mathrm{~cm}$, where a sandstone truncates a pebbly mudstone along a surface inclined at $40^{\circ}$; and at $349-12-5,120 \mathrm{~cm}$, where a pebbly mudstone truncates a massive, bioturbated mudstone along a surface inclined approximately $45^{\circ}$.

\section{Sedimentary Basalt Breccias}

Broken fragments of basalt forming prominent breccias are present above and within in situ basalt at Sites 336, 345, and 350. Those at Site 336 on the IcelandFaeroe Plateau are orange, red, and yellow, about 5 meters thick and show evidence of subaerial weathering by the presence of goethite and repetitive zones sedimentation and weathering (see later section on redbeds).

Breccias at Site 345 in the Lofoten Basin irregularly alternate with basalt (possibly simply large fragments), contain some reddish colors, may be as thick as 40 or more meters, and also contain goethite, suggestive of subaerial weathering. In contrast, breccias at Site 350 south of the Jan Mayen Ridge are about 3 meters thick, contain abundant zeolites and calcite veins, and are characterized by olive-gray to olive-black colors, showing no evidence of subaerial weathering.

\section{Synsedimentary Rip-up Clasts}

Claystone, mudstone, and sandy mudstone clasts are found commonly in several turbidite sequences. The clasts are apparently derived from the ripping-up or erosion during the passage of turbidity currents of previously deposited fine-grained sediment on the ocean floor; the clasts may be concentrated at the base of the resulting turbidite deposit, irregularly scattered throughout the bed, or, more rarely, concentrated in the middle or top of the bed. The clasts also show evidence of deformation during transport, as many are. folded and broken by minor faults. The clasts may be quite large, ranging up to $10 \mathrm{~cm}$ or more in thickness. The synsedimentary clasts are also concentrated in some ungraded pebbly mudstone units that contain randomly oriented and scattered clasts set in a mudstone matrix and lack Bouma sequences (Figure 10). The deposits probably result from submarine debris flows initiated by downslope slumping of bedded deposits along basin-margin slopes.

Rip-up clasts were observed primarily in lower Eocene to Oligocene turbidite sequences at Sites 343, 345,349 , and 350 , although scattered occurrences in other types of sequences have also been noted. The main occurrences noted are shown in Table 1 .

The synsedimentary rip-up clasts are sometimes mixed with small lithic pebbles of igneous or metamorphic derivation, especially in some of the thicker pebbly mudstone units and occasionally at the base of thinner 


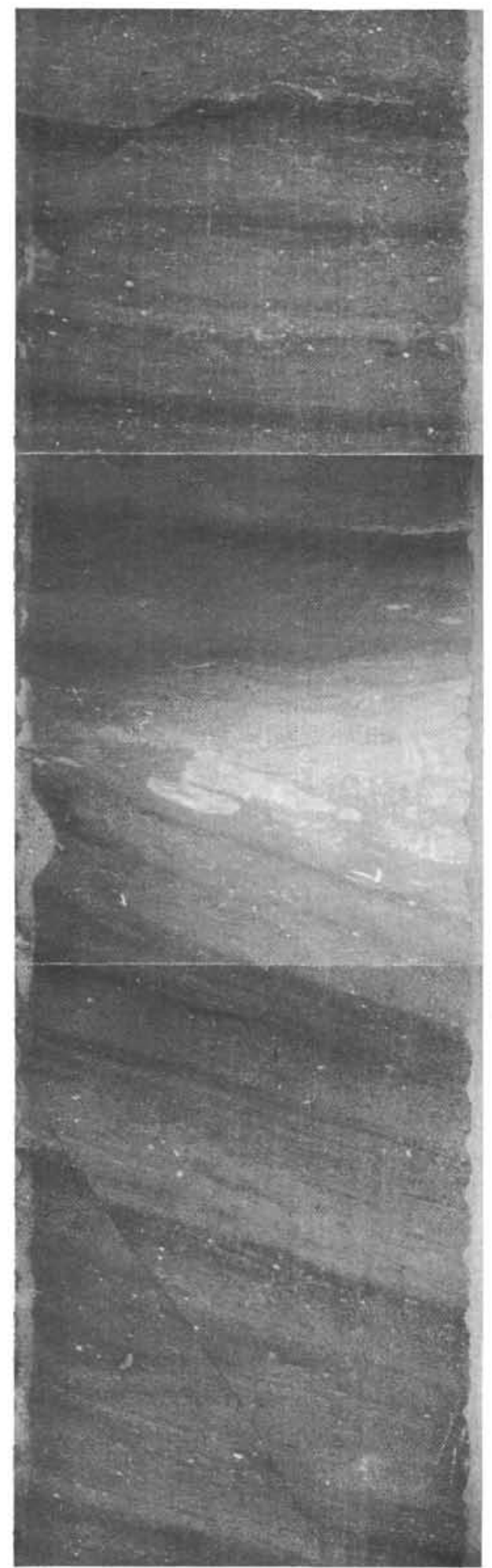

Figure 8. Angular unconformity developed in upper Eocene(?) mudstone sequence and marked by conglomeratic layer, $345-$ 23-2, $70 \mathrm{~cm}$ (from left to right). Note faults, possibly of synsedimentary origin, above and below unconformity.

turbidite beds. In general, however, the rip-up clasts comprise $90 \%$ or more of the conglomeratic material in the turbidite sequences. However, within the "glacial"

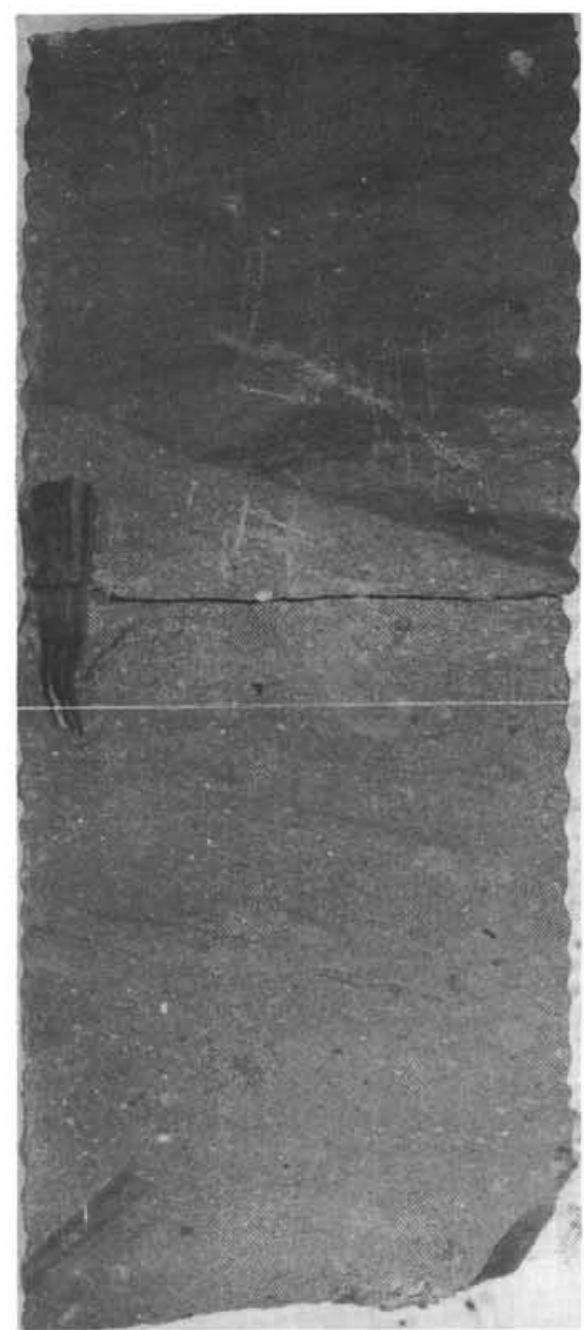

Figure 9. Angular unconformity in upper Eocene mudstone sequence, 345 $25-3,95 \mathrm{~cm}$. Note mudstone rip-up clasts below and pseudoparallel lamination above the unconformity surface.

sediments in the upper parts of most holes, and in the weathered rubble resting on basalts in the lower parts of most holes, the lithic igneous and metamorphic pebbles predominate.

\section{Ice-rafted Pebbles}

Scattered pebbles of various lithologies, attributed to ice-rafting processes, are common in Pliocene and Pleistocene sequences from virtually every hole (see White, this volume, table 12). Unfortunately, these semiconsolidated sediments were generally so deformed during coring operations that clear evidence of dropstone origin for the pebbles, such as deformed strata beneath the pebbles, was not seen.

\section{SECONDARY SEDIMENTARY STRUCTURES AND FEATURES}

\section{Pyrite Nodules}

Pyrite, both as scattered, fine-grained material and as larger nodules, is a common constituent of a number of 


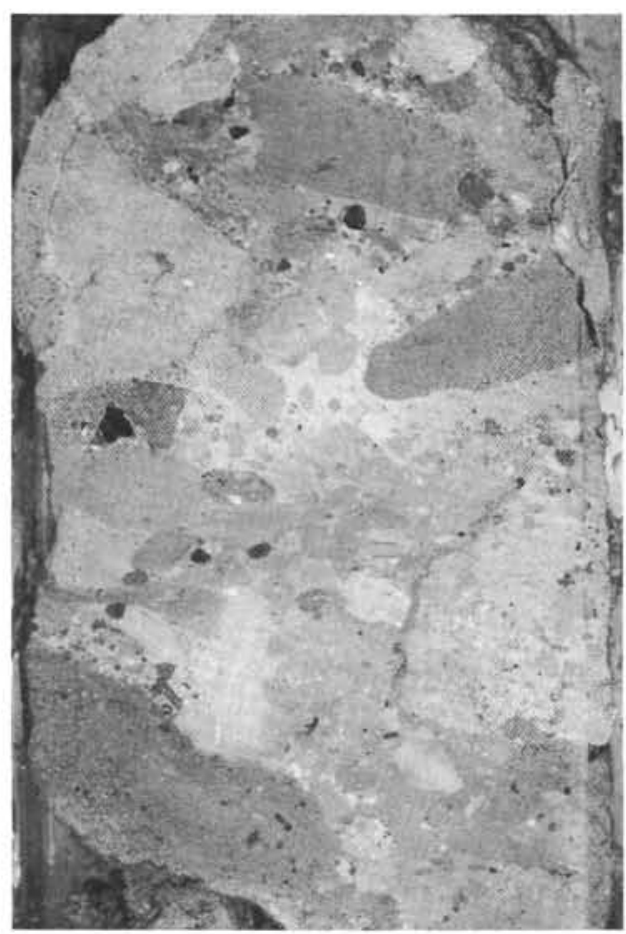

A

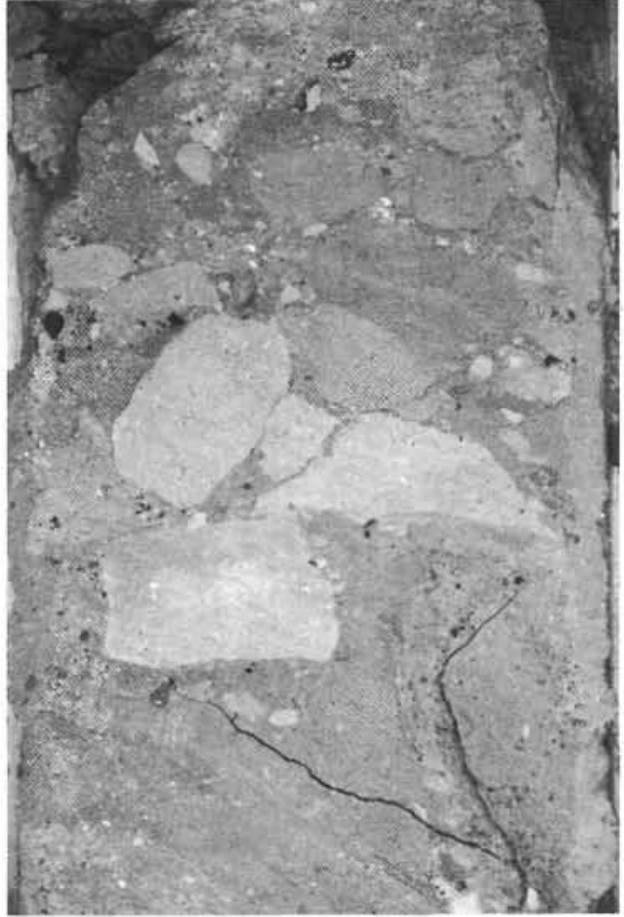

B

Figure 10. Synsedimentary rip-up clasts in upper Eocene pebbly mudstone sequences, Jan Mayen Ridge. (a) $349-10-2,110 \mathrm{~cm}$. (b) $349-10-3,35 \mathrm{~cm}$.

stratigraphic units in Leg 38 cores (see White, this volume, table 11). Pyrite seems to be particularly concentrated in strata that directly overlie basalt on the V $\phi$ ring Plateau, Lofoten Basin, and Icelandic Plateau. The pyrite nodules are fairly common in some dark greenish-gray and olive-black mudstones (Figure 11) of Oligocene and late Eocene age that also commonly contain very few fossils, suggesting deposition in restricted or possibly oxygen-poor environments; this, combined with migration of iron from underlying basalts, has probably concentrated pyrite in these sequences. Most of the nodular pyrite probably forms in burrows, as can be seen in Figure 11 (see section on trace fossils).

\section{Calcareous Concretions and Calcite Veins}

Calcareous concretions are relatively common in Leg 38 cores and are particularly associated with coarsegrained turbidites and angular unconformities in Eocene and Oligocene sequences (see Figures 4 and 8). Within these sequences, hard and resistant concretionary turbidite sandstone layers, which may be calcareous along the entire lateral extent of the layer rather than in discrete spherical or ellipsoidal concretions, can be observed at $345-24-3,130 \mathrm{~cm} ; 345-28-0$, $0-45 \mathrm{~cm} ; 345-28-5,0-32 \mathrm{~cm} ; 345-30-5,129-147 \mathrm{~cm}$; and $350-12-1,65-90 \mathrm{~cm}$ and $130-150 \mathrm{~cm}$. Concretionary mudstone layers within the turbidite sequence, but not associated directly with turbidite sandstones, were observed at $345-21-3,18-20 \mathrm{~cm} ; 345-25-6,137 \mathrm{~cm}$ to $345-25-6, C C ; 349-10-5,80-90 \mathrm{~cm} ; 350-12-2,0-5 \mathrm{~cm}$; $350-13-2,0-15 \mathrm{~cm}$ and $132-150 \mathrm{~cm}$; and $350-13-3,0-12$ $\mathrm{cm}$. Concretionary zones of both types are very com- mon at Site 348, Cores 24-32 and Site 350, Cores 9-14. Movement of calcareous interstitial waters through the porous sandstones and along the contacts between different lithologic units undoubtedly resulted in precipitation of calcite in available pore space. In several cases, calcareous concretions and veining are related to post-depositional faulting of the sequence, as at 345-21-6, 10-30 cm. Veinlets of calcite have also been observed in five holes (see White, this volume), generally in sediments overlying basalt, as well as within in the basalts, suggesting that the source for at least some of the migrating calcareous water was the basalts themselves. Other concretions, particularly those irregularly distributed in younger sediments, may have derived dissolved calcareous material from nannofossil oozes or other calcareous sediments. A few areas of concretionary carbonate material did not react to application of hydrochloric acid, and may consist of dolomite or siderite (Figure 8).

\section{Load Casts}

Load casts are bulbous or irregularly shaped downward protrusions of sand that result from load deformation of underlying mud. They are commonly produced at the base of turbidites, where irregular surfaces produced by sole markings and scour yield an unequal distribution of load, but are also commonly found in other situations of rapid deposition of sand on consolidated mud. Load casts were found in several lithified turbidite sequences; in the younger, less consolidated sedimentary sequences, their recognition was more difficult because of core deformation. Figure 12 
TABLE 1

Occurrences of Synsedimentary Rip-Up Clasts in Leg 38 Cores

\begin{tabular}{|c|c|}
\hline $\begin{array}{l}\text { Hole, Core, Section } \\
\text { (Interval in } \mathrm{cm} \text { ) }\end{array}$ & Remarks \\
\hline $\begin{array}{l}343-12-2,0-5,19-21,38-62 \\
62-70,102-107,110-120\end{array}$ & Units contain Bouma sequences \\
\hline $345-29-1,125$ & $\begin{array}{l}\text { At base of Bouma } T_{\text {acde }} \text { sequence } \\
(60 \mathrm{~cm})\end{array}$ \\
\hline $345-30-2,75(?)$ & $\begin{array}{l}\text { At base of Bouma } T_{\text {abde }} \text { sequence } \\
(55 \mathrm{~cm})\end{array}$ \\
\hline $\begin{array}{l}345-30-2,100 \text { to } \\
345-30-3,110\end{array}$ & $\begin{array}{l}\text { In pebbly mudstone unit } \\
(150 \mathrm{~cm})\end{array}$ \\
\hline $345-30-4,102-120$ & In pebbly mudstone unit $(18 \mathrm{~cm})$ \\
\hline $345-31-2,75,102-107$ & $\begin{array}{l}\text { Clasts concentrated at top of } \\
\text { the thicker pebbly mudstone } \\
\text { units; mudstone lithics not } \\
\text { synsedimentary }\end{array}$ \\
\hline $345-31-3$ to $345-31, \mathrm{CC}$ & In massive pebbly mudstone \\
\hline $\begin{array}{l}349-8-1,30-80 \\
349-9-1,80-90,95-103 \\
349-10-1,25-52,65-103 \\
105-110\end{array}$ & $\begin{array}{l}\text { In deformed pebbly sandy mud- } \\
\text { stone units }\end{array}$ \\
\hline $349-10-2,60$ to $349-10-4,55$ & $\begin{array}{l}\text { Continuous sequence of pebbly } \\
\text { mudstone. (see Figure 10a) }\end{array}$ \\
\hline $349-10-4,90-105$ & Pebbly mudstone \\
\hline $349-11-1,137$ to $349-11-2,5$ & $\begin{array}{l}\text { Two or three thin pebbly mud- } \\
\text { stone units }\end{array}$ \\
\hline $349-12-5,85-120$ & $\begin{array}{l}\text { In ungraded massive pebbly } \\
\text { mudstone }\end{array}$ \\
\hline $349-13-2,70-73,79-82$ & $\begin{array}{l}\text { Thin conglomeratic sandstones } \\
\text { of Bouma } \mathrm{T}_{\mathrm{ae}} \text { sequences }\end{array}$ \\
\hline $349-13-2,105$ to $13-4,25$ & $\begin{array}{l}\text { Series of massive pebbly mud- } \\
\text { stone units }\end{array}$ \\
\hline $349-13-4,60-75,120-135$ & $\begin{array}{l}\text { Two thinner ungraded pebbly } \\
\text { mudstone units }\end{array}$ \\
\hline $\begin{array}{l}349-13-5,55-70,130 \text { to } \\
349-13-6,100,125-145\end{array}$ & $\begin{array}{l}\text { Three graded pebbly mudstone } \\
\text { beds }\end{array}$ \\
\hline $350-10-1,90-93$ & $\begin{array}{l}\text { At base of Bouma } T_{\text {ade }} \text { sequence } \\
(13 \mathrm{~cm})\end{array}$ \\
\hline $350-10-1,145-148$ & $\begin{array}{l}\text { At base of Bouma } T_{\text {abde }} \text { sequence } \\
(22 \mathrm{~cm})\end{array}$ \\
\hline $350-10-2,132-135$ & $\begin{array}{l}\text { At base of complex turbidite } \\
\text { (see Figure 10b) }\end{array}$ \\
\hline $350-12-1,65-75$ & $\begin{array}{l}\text { At top of thin reverse graded } \\
\text { pebbly sandstone }\end{array}$ \\
\hline
\end{tabular}

shows a good example of small load casts developed at the base of a thin sandy mud turbidite layer within an extensively bioturbated mudstone sequence; in this case, bioturbation may have contributed partly to the complex pattern of load casting.

\section{Dish Structures}

Dish structures were noted within Oligocene terrigenous turbidite strata from Hole 350-10-2, 60-85 $\mathrm{cm}$ and also possibly from $345-30-3,14 \mathrm{~cm}$. Dish structures were first observed in thickly bedded medium- to coarse-grained sandstones within flysch sequences of lower Tertiary age from the Coast ranges of central and northern California (Wentworth, 1967; Stauffer, 1967);

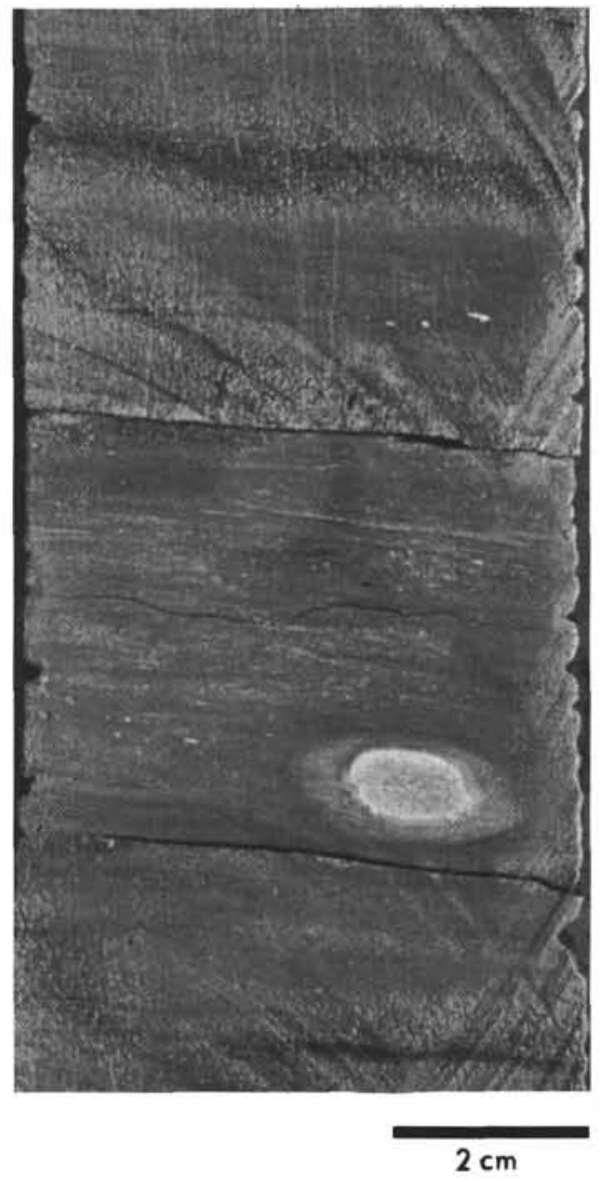

Figure 11. Pyrite nodule from Eocene(?) mudstone, 345-30-1, $65 \mathrm{~cm}$. Note pseudoparallel stratification in mudstone and halo around pyritic core of nodule, which is a pyritized burrow, possibly Planolites.

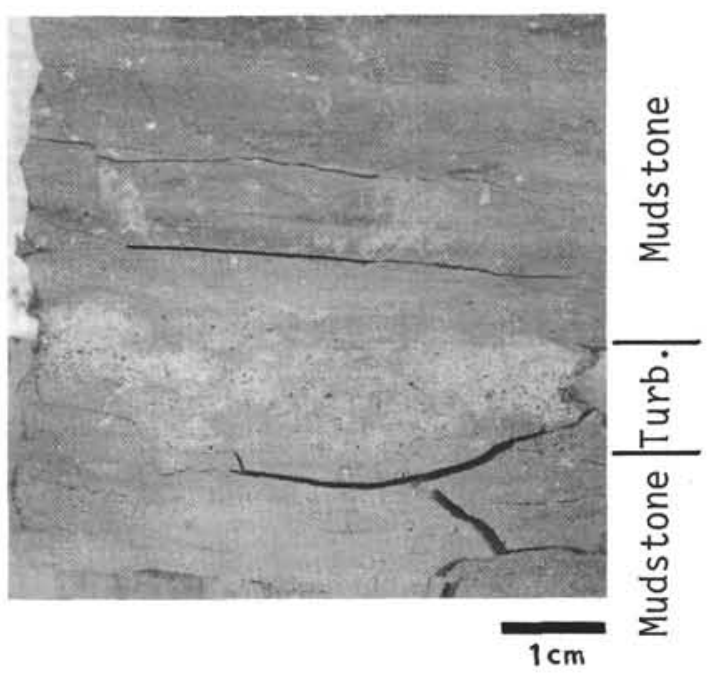

Figure 12. Load casts developed at the base of a thin upper Eocene(?) sandy mud turbidite layer at 345-22-4, $127 \mathrm{~cm}$. Note also pseudoparallel stratification in mudstone above and below. 
these sandstones were thought to have been deposited by mass flow or grain flow processes at bathyal depths or even deeper. Middleton and Hampton (1973) suggested that dish structure is characteristic of sediments deposited by fluidized sediment flows, in which sands are transported in a liquefied or quick condition. Lowe and LoPiccolo (1974) concluded that dish structures result from the escape of water during the compaction of underconsolidated or quick beds of silt. sand, or fine gravel.

The structures from Site 350 occur within a mediumgrained sandstone and are defined by distinctly concave-upward dishes that average about $1 \mathrm{~cm}$ in thickness and probably $10-15 \mathrm{~cm}$ in width (Figure 13). They are defined individually by clay-rich dark colored laminae that grade upward into clay-poor sandstone. thus presenting the appearance of being reversely graded. They are clearly not current ripple markings because they lack foresets and not wave ripples because they are not symmetrically superimposed.

The sequence of Oligocene strata within which the dish structures are found also commonly contains graded sandstone and siltstone layers as thick as $40 \mathrm{~cm}$ with rounded claystone clasts concentrated at or near the base. The dish structures, however, occur within a thicker, somewhat complexly organized turbidite bed that extends from about $58-135 \mathrm{~cm}$ in Core 10 , Section 2. This bed consists of (1) a basal 3-4 cm of rip-up conglomerate that grades upward into (2) about $25 \mathrm{~cm}$ of graded, parallel-laminated sandstone with scattered small rip-up clasts, (3) $25 \mathrm{~cm}$ of massive graded mudstone with scattered granule-sized clasts, (4) $25 \mathrm{~cm}$ of fine- to coarse-grained sandstone with dish structures, (5) $2 \mathrm{~cm}$ of parallel-laminated fine-grained sandstone, and (6) $0.5 \mathrm{~cm}$ of massive mudstone (Figure 12). The entire bed, approximately $80 \mathrm{~cm}$ thick, may consist of a single complex turbidite, inasmuch as it is broadly graded from base to top, or two separate events, separable at the base of the dish-structured unit. The association of the dish structures with a thick, complexly graded turbidite unit suggests in part transport of the sand in a fluidized or quick state, with postdepositional explusion of water.

\section{Preconsolidation Deformation}

Preconsolidation deformation was observed in several cores as contorted stratification, folding, and minor faulting indicative of movement of sediment after deposition. In almost every case, the structures are associated with turbidite sequences and probably resulted from downslope slumping and transport of semiconsolidated sediment on the sea floor; associated pebbly mudstone deposits, probably derived from submarine debris flows, also suggest instability of the depositional sites.

Irregularly laminated mudstone that is folded and contorted along subhorizontal axial planes is present in upper Eocene turbidites of $350-13-2,30-55 \mathrm{~cm}$. The mudstone contains laminae $1 \mathrm{~mm}$ to $1 \mathrm{~cm}$ thick, is somewhat coarser grained than underlying and overlying mudstones, and probably was emplaced by slumping. The folded unit rests unconformably on the underlying mudstone. Other possible examples of softsediment deformation were observed in muds of 339-4$4,0-120 \mathrm{~cm}$ and $339-5-1,110-140 \mathrm{~cm}$, associated with diapiric intrusions, and in muds at $342-2-3,343-2-3$, $344-28-2,58-63 \mathrm{~cm} ; 344-30-1,90-105 \mathrm{~cm}$; and 344-30-1, $10 \mathrm{~cm}$ to $344-30-2,150 \mathrm{~cm}$. Faults of possible softsediment origin were noted at 345-6-2, 345-8-4, and $348-26-2,130 \mathrm{~cm}$, and uncertainly noted in many other cores; faults possibly associated with an unconformity were noted at 345-23-2, $70 \mathrm{~cm}$ (see Figure 8).

A prominent fault of probable dip-slip motion and containing abundant calcite veinlets and concretionary zones is present at $345-21-6,10-30 \mathrm{~cm}$. The fault truncates a massive graded siltstone-sandy mudstonemudstone-claystone turbidite that is $5-10 \mathrm{~cm}$ thick and similar to numerous other thin turbidites in this thick Oligocene sequence. During movement on the fault, the turbidite bed was broken, brecciated fragments of it were incorporated in the fault zone, and calcite veinlets developed as thin sills within it. Claystone in the upper plate was folded and contorted as a result of the movement, and calcite later crystallized in the sediment, forming a hard concretionary zone; this zone was later further brecciated during compaction or possibly continued movement on the fault. The amount of displacement on the fault is indeterminable, but probably is not more than a few tens of centimeters.

Zones of brecciation are relatively common in the deeper parts of many holes, where sediments are lithified. The time of formation of many of these breccias is problematical; most are clearly caused by fracturing of the rock during drilling (good examples may be seen at $346 \quad 18-3$ and $346-20-2$ ), others are depositional breccias or rubble formed on weathered basalt (i.e., Site 336, Core 39 to 40; Site 345, Section 323 to 36-1; and Site 350, Section 14-2 to 16-1), and others may have been derived from preconsolidation slumping and sliding (such as those at $344-28-2,58-63 \mathrm{~cm}$ and the thick sequence of pebbly mudstones in upper Eocene rocks of Site 349).

\section{Pseudoparallel Stratification}

This term is applied to a variety of markings that are oriented subparallel to stratification, but which result from compaction of trace fossils of various shapes and sizes in fine-grained sediments rather than from current-formed lamination or alternating bands of different lithology. Trace fossils that are oriented subparallel to bedding, when subjected to compaction of $50 \%$ or more, produce a pseudoparallel stratification (see Figures 8, 9, 11, and 12). The feature is most extensively developed in thick sequences of claystone, mudstone, and sandy mudstone, such as at Sites 345 and 350 . The pseudostrata in each hole become more closely spaced and well-defined with increasing depth, undoubtedly a result of greater compaction, reorientation of clay minerals, and expulsion of water from the lithifying sediment.

\section{TURBIDITES}

Turbidites were observed at a number of Leg 38 sites, but are particularly well-developed in lower Eocene to Oligocene terrigenous sedimentary rocks at Sites 343, 345,349 , and 350 . Two different and distinctive turbidite types were observed.

The first type consists of graded conglomerate, sandstone, and siltstone layers that repetitively alternate with massive sandy mudstone, mudstone, and 

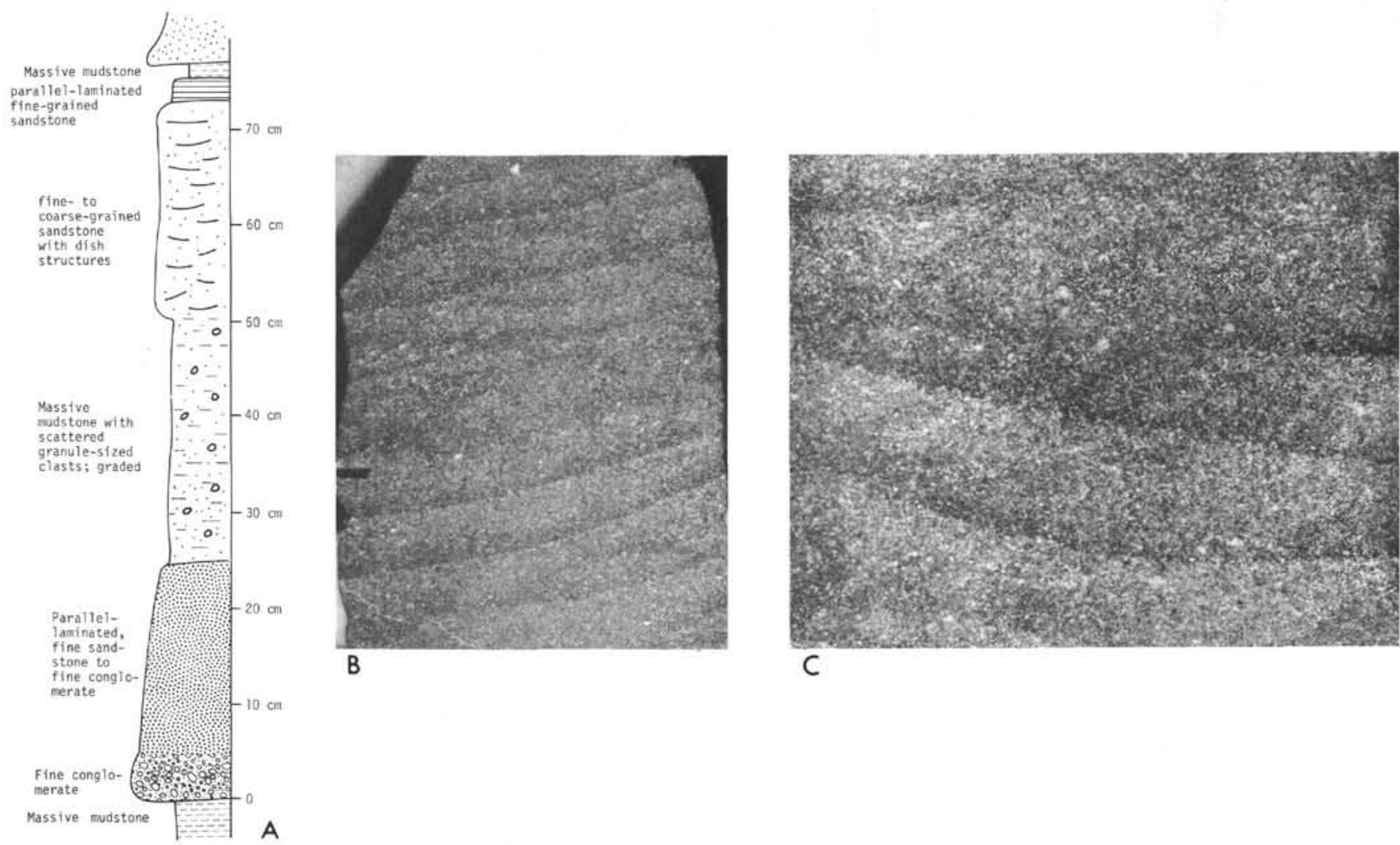

C

Figure 13. Dish structures, 350-10-2. (a) stratigraphic column showing position of dish-structure interval (note vertical scale starts at base of turbidite sequence). (b) dish structures, 10-2, 75-83 cm. Scale $1 \mathrm{~cm}$ on photo $=1 \mathrm{~cm}$ of core. (c) dish structures, $10-2,80-82 \mathrm{~cm}$. Scale $1 \mathrm{~cm}$ on photo $=0.5 \mathrm{~cm}$ on core.

claystone, forming sequences as thick as several hundred meters. The individual coarse-grained layers are generally organized into Bouma (1962) sequences, and the vertical stacking of layers commonly forms thinning-upward and fining-upward cycles. In some holes these turbidites are associated with thick pebbly mudstones and contain abundant synsedimentary ripup clasts, preconsolidation deformation structures, and minor unconformities. The fine-grained hemipelagic interlayers are generally extensively bioturbated, contain pseudoparallel lamination, and are predominantly terrigenous in origin. In general, the uppermost $T_{e}$ mudstone of the Bouma sequence, which results from deposition of the fine-grained material from the turbulent suspension, can be distinguished from the intervening hemipelagic mudstone by the general absence of bioturbation; it apparently is deposited too rapidly on the newly formed turbiditic sediment cover for the establishment of burrowing organisms. These turbidites were deposited by turbidity currents that flowed downslope along the sea floor, scoured the bottom, and deposited sediments in a graded, sequential order as current velocities gradually decreased. These turbidites in Leg 38 cores are almost exclusively of Eocene and Oligocene age.

The second type of turbidite consists of graded sandstone or siltstone layers tyat occur sporadically within various types of fine-grained sediment, including oozes of biogenic origin and Pleistocene clays deposited primarily by ice rafting. These turbidites do not form repetitively alternating thick sequences of coarse- and fine-grained layers, but are present as isolated layers that do not form thinning-upward or fining-upward cycles. Bouma sequences are generally not present in these turbidites. They are thought to have been deposited by turbulent suspensions of sediment that flowed over the top of or within ocean waters, rather than along the bottom of the sea floor. These sedimentladen overflows and interflows, probably caused by large floods on adjacent land areas during glacial and interglacial periods, then settled vertically through the oceanic water column, yielding graded layers without cross-stratification, parallel lamination, convolute lamination, and other sedimentary structures characteristic of Bouma sequences. This second type of turbidite in Leg 38 cores is generally of Neogene age.

\section{Neogene Turbidites}

At Site 336, a series of isolated graded layers of volcanic sand and sandy mud was observed in 336-9-4 and $336-9-5$, in moderately to intensively deformed Pliocene strata. In 336-9-5, Bouma $T_{\text {de }}$ and $T_{\text {cde }}$ sequences with the possible presence of some convolute lamination were recognized, although core deformation was intense. These turbidites are located within a thick, massively bedded Pliocene hemipelagic unit, and thus do not form part of a well-developed thicker turbidite sequence. They may represent downslope movement of 
sediment from the top of the Iceland-Faeroe Plateau during major storm periods at a time when the plateau was close to sea level.

At Site 341 , thin graded silt interbeds $1-4 \mathrm{~cm}$ thick were observed in Pliocene or Pleistocene sediments on the V $\phi$ ring Plateau in $341-20-6$ and $341-21-1$ to 6 . The silt interbeds are present within a thick sequence of marly calcareous ooze and calcareous mud, and sedimentary features of the Bouma sequence were not observed. These graded layers may represent deposition from vertical settling of overflows of sediment-laden glacial meltwaters during large floods extending off the west coast of Norway rather than deposition by bottom-flowing turbidity currents.

At Site 342, two fairly thick graded mud layers were observed in Pleistocene sediments on the $\mathrm{V} \phi$ ring Plateau in $342-1-4,40-70 \mathrm{~cm}$ and $342-1-6,30-80 \mathrm{~cm}$. Neither contains a Bouma sequence, and they may have the same origin as the fine-grained graded layers from Site 341.

At Site 343, graded(?) "glacial" (Pleistocene) silts and sandy muds of possible turbidite origin were observed in Cores 3 and 4 . These sediments, located at the base of the seaward margin of the $\mathrm{V} \phi$ ring Plateau, do not contain Bouma sequences, and their origin is unclear.

At Site 344, located near Knipovich Ridge, graded mud and silt layers of possible turbidite origin were observed in sediments of Miocene or early Pliocene to "glacial" age in 344-11-1, $93 \mathrm{~cm}$; 344-13-1, 130-145 cm; 344-28-1, 112-117 cm; 344-28-2(?); 344-30-1, 90-105 cm; $344-31-1,83-102 \mathrm{~cm} ; 344-31-2$ and $3 ; 344-32-1$ and 2 , and 344-33-1, 2, and 3. The graded beds in Cores 11 and 13 consist of two thin isolated terrigenous sandy mud and silt layers within a thick sequence of mud presumably deposited by ice-rafting processes. The two layers do not contain sedimentary structures of the Bouma sequence and may have an origin similar to the isolated graded layers at Sites 336, 341, 342, and 343. The sediment source is most likely Spitsbergen or an adjacent part of the Barents Shelf.

The graded layers near the bottom of Site 344 , from Core 28 to Core 33 , form a poorly dated Miocene or Pliocene sequence approximately 120 meters thick that rests directly on basalt. The sequence consists wholly of terrigenous mudstone, sandy mudstone, siltstone, and sandstone. Synsedimentary rip-up breccias, contorted and/or convolute laminae with possible synsedimentary faults, one occurrence of cross-stratification, bioturbated mudstones between the graded layers, load casts(?), pyrite nodules, abundant calcareous concretions, and some thin parallel laminated Bouma $T_{\text {de }}$ units (especially in $33-2,67-73 \mathrm{~cm}$ ) characterize these strata. The sequence may consist of a fining-upward and thinning-upward cycle, inasmuch as the lowermost graded layers extend from $33-3,150 \mathrm{~cm}$ to $33-2,100 \mathrm{~cm}$ (200 cm thick), $33-2,100 \mathrm{~cm}$ to $33-1,125 \mathrm{~cm}(125 \mathrm{~cm}$ thick), and $33-1,125 \mathrm{~cm}$ to $33-1,63 \mathrm{~cm}(62 \mathrm{~cm}$ thick). However, the coring gap between Cores 32 and 33 prevents further examination of this vertical trend, although graded layers in Cores 28 to 32 are generally much thinner and less frequent. The general lack of well-developed Bouma sequences, the fine-grained nature of the sediments, and the predominance in thickness of bioturbated mudstone in these cores suggest possible deposition by overflows or interflows of sediment-laden floodwaters similar to that suggested for Sites 336, 341, 342, and 343, rather than by bottomflowing turbidity currents. The sediment source was probably Spitsbergen or the adjacent Barents Shelf.

At Site 345 , an isolated graded turbidite layer is present at 345-5-4 within sediments of "glacial" (lower Miocene) age. Situated within the Lofoten Basin, this single layer may represent the distal deposit of a longtraveled turbidity current derived from the coast of Norway or the $V \phi$ ring Plateau to the east.

Neogene turbidites were not recovered in Holes 346 to $352 \mathrm{~A}$, probably mainly because these holes were all drilled on basement ridges far from land source areas (Figure 1). The Jan Mayen Ridge (Sites 346, 347, 349, and 350) Iceland Plateau (Site 348), and Iceland-Faeroe Plateau (Holes 352, 352A) were all probably topographically high during the Neogene, and thus poor sites for deposition of turbidites.

\section{Paleogene Turbidites}

The following Paleogene turbidite sequences were observed in Leg 38 cores: (1) about $130 \mathrm{~cm}$ of thinly layered lower Eocene turbidites near the base of Site 343 , Samples $12-1,140 \mathrm{~cm}$ to $12-2,120 \mathrm{~cm}$, along the seaward flank of the V $\phi$ ring Plateau; (2) about 261.5 meters of thinly to thickly layered Oligocene and upper Eocene turbidites in the lower part of Site 345, Samples $20-3,140-145 \mathrm{~cm}$ to Core $30-5,150 \mathrm{~cm}$, near the western edge of the edge of the Lofoten Basin; (3) about 46 meters of mostly massive Eocene or older mudstone and sandy mudstone with irregular intercalations of thin turbidite and possible turbidite layers in the lower part of Site 346. Samples $15-2,135-150 \mathrm{~cm}$ to $20-1,150$ $\mathrm{cm}$, northern Jan Mayen Ridge; (4) at least $132 \mathrm{~cm}$ of predominantly thickly layered upper Eocene turbidites and pebbly mudstones at the base of Site 349 , Samples $10-1,102-109 \mathrm{~cm}$ to Samples 13-6, $145 \mathrm{~cm}$, southern Jan Mayen Ridge; and (5) about 87 meters of thinly to thickly layered upper Eocene to Oligocene turbidite layers in the lower part of Site 350, Samples 10-1, $80 \mathrm{~cm}$ to $13-3,12 \mathrm{~cm}$, on a ridge aligned with and south of Jan Mayen Ridge.

The lower Eocene turbidites at Site 343 rest directly on basalt; the lowermost layer contains open framework conglomerate breccia at its base that grades upward into massive sandstone with granule-sized clasts, a total layer thickness of about $14 \mathrm{~cm}$. The clasts at the base, as large as $2.5 \mathrm{~cm}$, are subangular to subrounded, and are composed mainly of mudstone. Overlying this basal layer are 12 additional graded turbidite layers that average about $10 \mathrm{~cm}$ in thickness and are organized into Bouma sequences, most commonly of the $\mathrm{T}_{\text {cde }}$ variety, but also including $\mathrm{T}_{\text {abcde }}, \mathrm{T}_{\text {abde }}$, and $T_{\text {ade }}$ sequences. Claystone and mudstone rip-up clasts are present at the base of several layers and in the middle of one $25-\mathrm{cm}$-thick $\mathrm{T}_{\text {ade }}$ layer. In general, the sequence thins upward, with the upper continuation not visible because of a coring void at the top of Core 12 , Section 1.

The thick Oligocene and upper Eocene turbidite sequence at Site 345 rests on about 13 meters of massive, structureless sandy mudstone with some intercalated sandstone and siltstone; toward the base of this un- 
derlying unit, scattered pebbles of chert, quartzite, and granitic rock are present. This unit overlies grayish-red subaerially weathered basalt breccia that presumably rests directly on basalt. The turbidites in general form a thinning- and fining-upward sequence. The upper part, from $20-3,140 \mathrm{~cm}$ to $27, \mathrm{CC}$, consists of about $70 \%$ of interlayered massive bioturbated hemipelagic mudstone and sandy mudstone; the turbidite layers are thin $(2-10 \mathrm{~cm})$, scattered in the vertical sequence, and consist mainly of Bouma $T_{d e}$ sequences with fine to medium sandstone at the base (Figure 2). The middle part of the turbidite sequence, from $28-1,0 \mathrm{~cm}$ to $30-1$, $112 \mathrm{~cm}$, contains less than $50 \%$ of interlayered massive bioturbated mudstone and sandy mudstone; the turbidite layers are thicker $(10-60 \mathrm{~cm})$, are grouped in the vertical sequence rather than scattered or isolated, and consist of more complete Bouma sequences $\left(\mathrm{T}_{\text {acde }}, \mathrm{T}_{\text {bede }}\right.$, $T_{\text {abce, }}, T_{\text {ade }}$, and $T_{\text {bde }}$ ) with some rip-up clasts and medium- to coarse-grained sandstone at the base. The lower part of the turbidite sequence, from $30-1,112 \mathrm{~cm}$ to $30-5,150 \mathrm{~cm}$, contains less than $20 \%$ interlayered mudstone; the turbidite layers are as thick as $200 \mathrm{~cm}$, rest on underlying turbidite layers rather than interlayered mudstone, contain abundant synsedimentary rip-up clasts as well as lithic clasts at the base, and contain some complete and near-complete Bouma sequences. In addition, some massive pebbly mudstone layers, deformed layering, and possible dish structures $(345-30-2,14 \mathrm{~cm})$ are present within the lower part of the sequence.

The middle Miocene or older turbidites from Site 346 consist of several isolated single beds at the top and at the base of the sequence, and a fairly continuous sequence of almost 3 meters in the middle of the sequence. At the top of the turbidite sequence, a single 32-cm-thick Bouma $T_{\text {ade }}$ layer with fine-grained sandstone at the base is present at $15-2,135 \mathrm{~cm}$ to $15-3$, $17 \mathrm{~cm}$, within a thick sequence of massive, bioturbated mudstone and sandy mudstone. In the middle part of the turbidite sequence, 10 turbiditic layers, $4-40 \mathrm{~cm}$ thick, are present from $18-1,10 \mathrm{~cm}$ to $18-2,139 \mathrm{~cm}$; these layers are graded and located within a massive, bioturbated sandy mudstone with scattered small pebbles and abundant worm tubes. The base of the turbidite sequence contains isolated thin single turbidite layers within bioturbated sandy mudstone at 19-3, 81$84 \mathrm{~cm}, 19-4,65-70 \mathrm{~cm}, 19-4,106-111 \mathrm{~cm}$, and possibly some in Core 20, Section 1. The spacing of turbidite layers is too scattered and erratic to form recognizable fining-upward cycles in this hole.

Site 349 contains perhaps the most interesting sequence of turbidites. Within it are abundant pebbly mudstones, very thick turbidites, a great variety of Bouma sequences and sedimentary structures, and prominent erosional interfaces. Unfortunately, the coring program permitted recovery of only four scattered cores within the sequence, and the base of the sequence was not penetrated; thus reconstruction of the vertical sequence in terms of turbidite facies and environments (Mutti and Ricci Lucchi, 1972) is difficult. The topmost core (10) contains, in descending order, about $90 \mathrm{~cm}$ of pebbly mudstone (Figure 14a), $110 \mathrm{~cm}$ of turbidites and interlayered mudstone, about $350 \mathrm{~cm}$ of pebbly mudstone (Figure 14b), and $350 \mathrm{~cm}$ of massive, bioturbated mudstone. Core 11, stratigraphically about 30 meters below the base of Core 10, contains, in descending order, about $90 \mathrm{~cm}$ of pebbly mudstone and pebbly sandstone with some interlayered massive sandstone; $75 \mathrm{~cm}$ of turbidites (a 47-cm-thick Bouma $\mathrm{T}_{\mathrm{bc}}$ sequence over a Bouma $\mathrm{T}_{\text {ade }}$ sequence); $133 \mathrm{~cm}$ of massive, bioturbated mudstone; $165 \mathrm{~cm}$ of turbidites (a 102-cm-thick Bouma $T_{\text {de }}$ sequence over a Bouma $T_{\text {bede }}$ sequence); $150 \mathrm{~cm}$ of massive, bioturbated mudstone; a $65-\mathrm{cm}$-thick Bouma $\mathrm{T}_{\text {bede }}$ turbidite; and at least $40 \mathrm{~cm}$ of massive, bioturbated mudstone. Core 12, stratigraphically about 30 meters below the base of Core 10 , contains, in descending order, at least $20 \mathrm{~cm}$ of massive mudstone; $25 \mathrm{~cm}$ of turbidites (a truncated Bouma $T_{a}$ medium sandstone over a $23-\mathrm{cm}$-thick $T_{d e}$ sequence); $70 \mathrm{~cm}$ of massive, bioturbated mudstone; $195 \mathrm{~cm}$ of turbidites, consisting of three layers organized into $\mathrm{T}_{\text {ae }}, \mathrm{T}_{\text {ade }}$, and $\mathrm{T}_{\text {ade }}$ sequences; $290 \mathrm{~cm}$ of massive, bioturbated mudstone; $25 \mathrm{~cm}$ of parallel laminated mudstone underlain by $35 \mathrm{~cm}$ of pebbly mudstone; and at least $45 \mathrm{~cm}$ of massive, unbioturbated mudstone. Core 13, stratigraphically about 40 meters below the base of Core 12, contains, in descending order, $160 \mathrm{~cm}$ of massive, unbioturbated mudstone; $365 \mathrm{~cm}$ of interlayered pebbly mudstone and mudstone, graded, thinner, and finer at the top, ungraded, thicker and coarser at the bottom; and $320 \mathrm{~cm}$ of three pebbly mudstone layers that grade upward into massive, bioturbated mudstone, the upper layer $85 \mathrm{~cm}$ thick, the middle $180 \mathrm{~cm}$ thick, and the lower at least $45 \mathrm{~cm}$ thick. Vertical cycles of thinning-upward or fining-upward are not clear from these cores; pebbly mudstones are most common in the uppermost and lowermost cores.

The upper Eocene turbidites at Site 350 rest on massive bioturbated and calcareous mudstone that directly overlies basalt breccia which in turn overlies basalt. No evidence for subaerial weathering is present, and presumably the turbidites were deposited on basalt formed in relatively deep marine water. Contorted layering and some faulting is present in the mudstones underlying the turbidites as well as within the lower turbidites, suggesting instability of the depositional site of the lower sedimentary sequence at Site 350 . Here, as at Site 349 , coring of the turbidites is incomplete, with four cores taken within a sequence that is about 87 meters thick. The turbidites consist of (1) an upper sequence, about $240 \mathrm{~cm}$ thick, from $10-1,80 \mathrm{~cm}$ to $10-3$, $20 \mathrm{~cm}$ containing dish structures in one layer (Figures 14c, 15); (2) a middle massive, bioturbated mudstone sequence, possibly as thick as 55 meters, containing some thin interlayered volcanic ash and locally scattered pebbles; (3) an isolated, graded, calcareous, medium- to very coarse grained sandstone, $20-\mathrm{cm}$-thick $(12-1,130-150 \mathrm{~cm}) ;(4)$ about $29 \mathrm{~cm}$ of massive, bioturbated mudstone with some interlayered volcanic ash; and (5) about $150 \mathrm{~cm}$ of massive, bioturbated mudstone with two graded, calcareous, parallel-laminated and partly contorted mudstone layers about $30-40 \mathrm{~cm}$ thick and one thin volcanic ash layer. Thinning-upward or thickening-upward cycles are not clear from the available data.

\section{REDBEDS}

Redbeds of probable subaerial origin were observed in cores from Sites 336 and 345 (see section on sedimentary basalt breccias, this paper). In contrast with the 


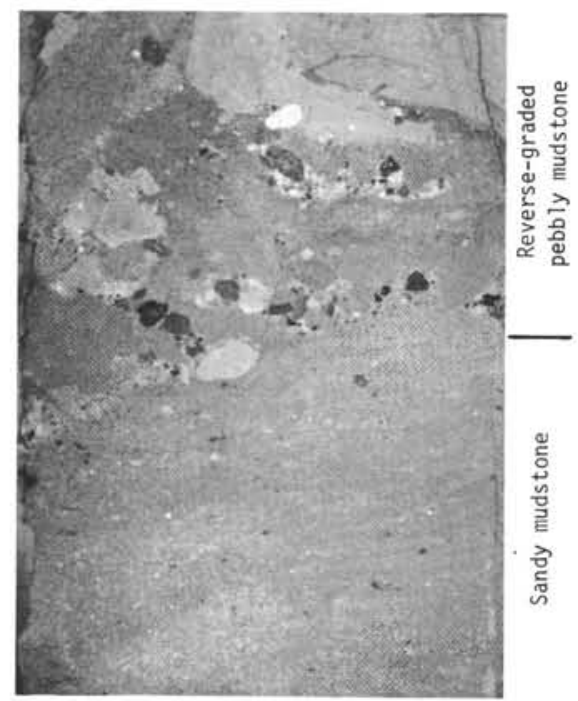

A

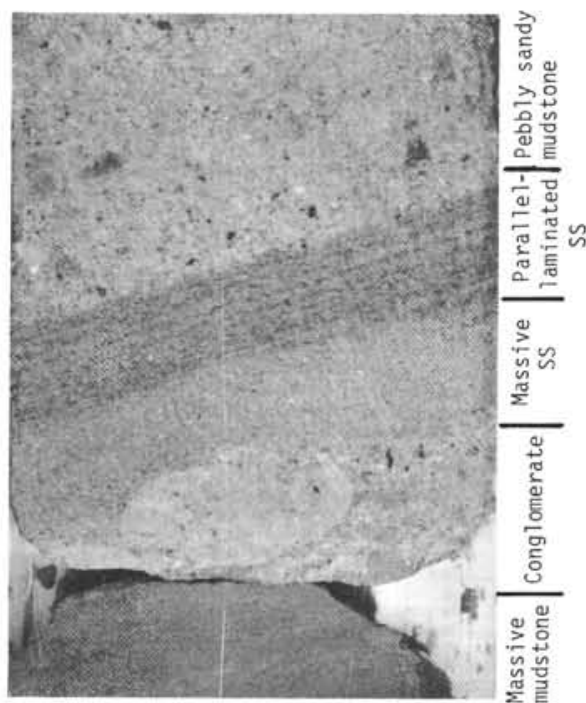

B

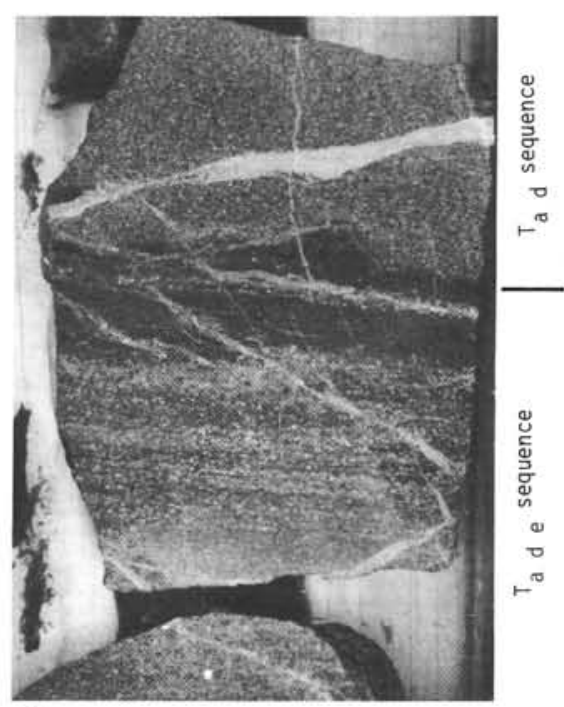

C

Figure 14. Bases of turbidite layers of varying lithology. (a) Base of reverse-graded pebbly mudstone containing deformed mudstone rip-up clasts, 349-10-2, 135-145 cm, upper Eocene. (b) In ascending order, massive mudstone, conglomerate, massive sandstone, parallel-laminated sandstone, and massive pebbly-sandy mudstone, $349-10-4,55 \mathrm{~cm}$ (base of conglomerate), upper Eocene; forms base of irregularly stratified, generally ungraded pebbly mudstone unit about $175 \mathrm{~cm}$ thick. (c) Scoured base of 7-cm-thick $T_{a d}$ sequence resting on mudstone layer at top of underlying 20-cm-thick $T_{\text {ade }}$ sequence, 350-10-1, $100 \mathrm{~cm}$ (scoured base); Oligocene; note abundant calcite veins.

redbeds of Site 345 , which form a stratigraphically simple and continuous vertical sequence of weathered basalt breccia or rubble, the redbeds of Site 336 on the Iceland-Faeroe Plateau form a 10 -meter-thick sequence of varying lithology and in part, of cyclic repetition of weathered and depositional intervals.

The redbed sequence of Site 336 extends from the top of the basalt basement of Core 41 to the base of the marine olive-black sandy mudstone of Core 37 . This sequence can be divided into four petrologic and stratigraphic units, in ascending order, basaltic rubble, red clay with altered basaltic clasts, interbedded red and pale orange clay, and red clay (see Figure 16).

The basaltic rubble $(453 \mathrm{~cm}$ thick) is characterized by a variety of upward changes, including: a decrease in average clast size and angularity, from $40 \mathrm{~mm}$ angular clasts to $10 \mathrm{~mm}$ subrounded clasts; an increase in matrix content and color intensity and variation, from greenish-black and dusky red with very little matrix at the base to dusky and dark red clasts with some bluishgray matrix in the middle and dusky and blackish-red clasts surrounded by a yellow-brown to dark yellow matrix at the top. X-ray diffraction analyses reveal an upward loss of feldspar, pyroxene, and olivine, the introduction of hematite, and constant presence of montmorillonite. Clasts in the basaltic rubble unit appear to be suspended in the matrix, only rarely appearing to be brecciated by the matrix; this suggests a weathering origin for the breccia rather than an origin by an intrusive mineralization process.

The contact between the basaltic rubble and the overlying unit of red clay with altered basaltic clasts appears to be an extremely altered zone. about $25 \mathrm{~cm}$ thick, characterized by extreme variations of green, blue, yellow, and red colors. The red clay, with altered basaltic clasts unit, composed primarily of montmorillonite and hematite, is about $140 \mathrm{~cm}$ thick and is a massive, moderate red clay with evenly dispersed 1$10 \mathrm{~mm}$-large black clasts, originally basaltic, but subsequently completely altered to clay. These clasts have a pseudomorphic volcanic texture. Scattered white "clasts" and a few interbedded pale orange clays with faint root-like structures like those in the overlying unit are also present.

The overlying interbedded red and pale orange clay unit is $205 \mathrm{~cm}$ thick. The moderate red clays have a higher montmorillonite content and fewer root-like structures than the pale orange clays, which are less abundant but have a higher kaolinite content. Content of kaolinite increases and montmorillonite decreases upward, while hematite, goethite, and anatase are constantly present. The white "clasts" observed in the underlying unit are also present. Layering becomes thinner and the frequency of pale orange clays increases toward the top.

The orientation, character, and relative density of the root-like structures (see Figure 17) are suggestive of an organic origin, perhaps root molds. These root-like features tend to be planar in views perpendicular to the core length in the pale orange layers, whereas in the red clays they are linear and seem to diverge downwards from the pale orange layers. The relative density of these root-like structures, with the densest areas arbitrarily assigned a value of 10 , permits rough division of the unit in thirds, suggesting rhythmic or cyclic events. The lower third has a minimum of 0 and max- 


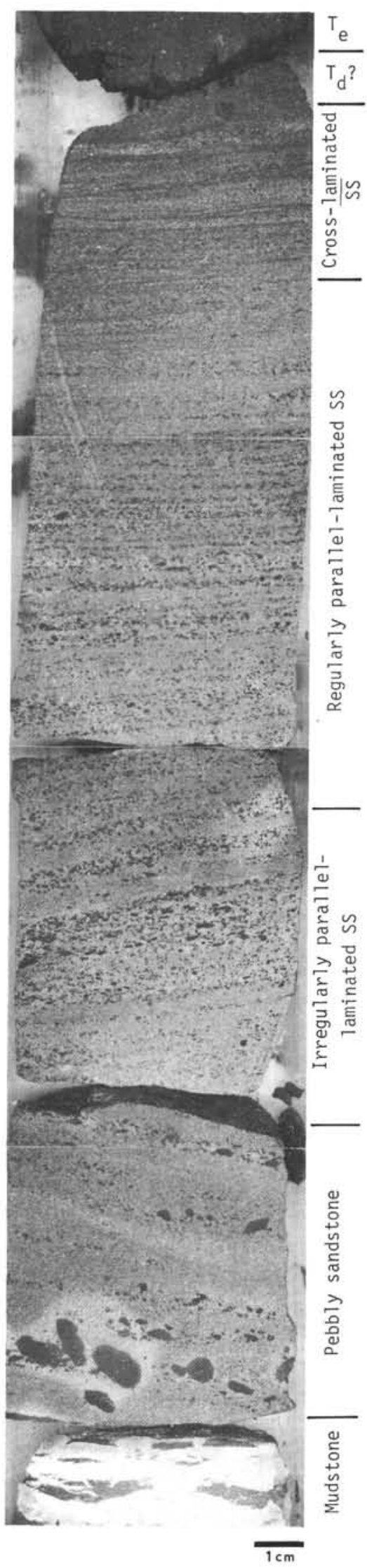

Figure 15. Base of graded Oligocene $T_{b c d e}$ turbidite layer, 350-10-2, $135 \mathrm{~cm}$ (basal) contact. Sequence consists, in ascending order, of underlying fractured mudstone filled with calcite veins, an irregularly stratified pebbly sandstone containing imbricated and rounded mudstone clasts as large as $1.5 \mathrm{~cm}$, irregularly parallel sandstone and pebbly layers grading upward into regularly parallel sandstone $\left(T_{b}\right)$, low-angle crosssandstone $\left(T_{c}\right)$, irregularly parallel-laminated siltstone $\left(T_{d}\right)$, and massive mudstone with some scattered pebbles ( $T_{e}$ ?). An interval with dish structures is located about $25 \mathrm{~cm}$ above base of topmost mudstone shown here (see Figure 14). Scale $1 \mathrm{~cm}$ on photo $=1 \mathrm{~cm}$ of core.

imum of 1 , the middle third has a minimum of 3 and a maximum of 5 , with intermediate peaks of 4 , and the upper third has minimums of $0,1,3$, and 4 and maximums of 8 and 10 with intermediate peaks of 4 .

The overlying red clay unit is $175 \mathrm{~cm}$ thick. It is a monotonous, dusky red to dark red-brown clay composed primarily of kaolinite, hematite, and goethite, with minor amounts of anatase.

It is concluded that the redbed sequence in the lower cores (38-40) of Site 336 was formed in situ by weathering of the basaltic basement and may represent a ferruginous lateritic paleosol. This conclusion is supported by (1) the upward decrease in grain size and development of clays from the basaltic rubble, (2) the upward change from weathered feldspar to montmorillonite to kaolinite, (3) the upward oxidation of ferrous iron minerals, principally pyroxene and olivine, to ferric iron minerals of hematite and goethite, (4) depletion of sodium, calcium, and magnesium in the upper unit. All of these trends are typical of ferruginous lateritic-type soils that are developing on basalts today.

The lateritic soils at Site 336 developed during the Paleogene although the exact time of formation is unclear because of dating problems. The potassium-argon dates from the underlying basalt yield a late Eocene age, whereas the base of the overlying marine sedimentary sequence is thought to be of middle or late Eocene age based on microfauna (see Site Report for Site 336, this volume). Early Tertiary ferruginous lateritic paleosols are present in other parts of the North Atlantic region and are particularly well developed on 60m.y.-old plateau basalts in Antrim, Northern Ireland, where they are thought to be of Paleocene or early Eocene age (Wilson, 1972). The reddish goethitebearing basalt breccia at Site 345 is of late Eocene or older age and may have developed at the same time as those at Site 336 .

\section{TRACE FOSSILS}

\section{Introduction}

Trace fossils are distinctively shaped biogenic sedimentary features or markings formed by sedimentdwelling benthonic animals that structured the sedi- 


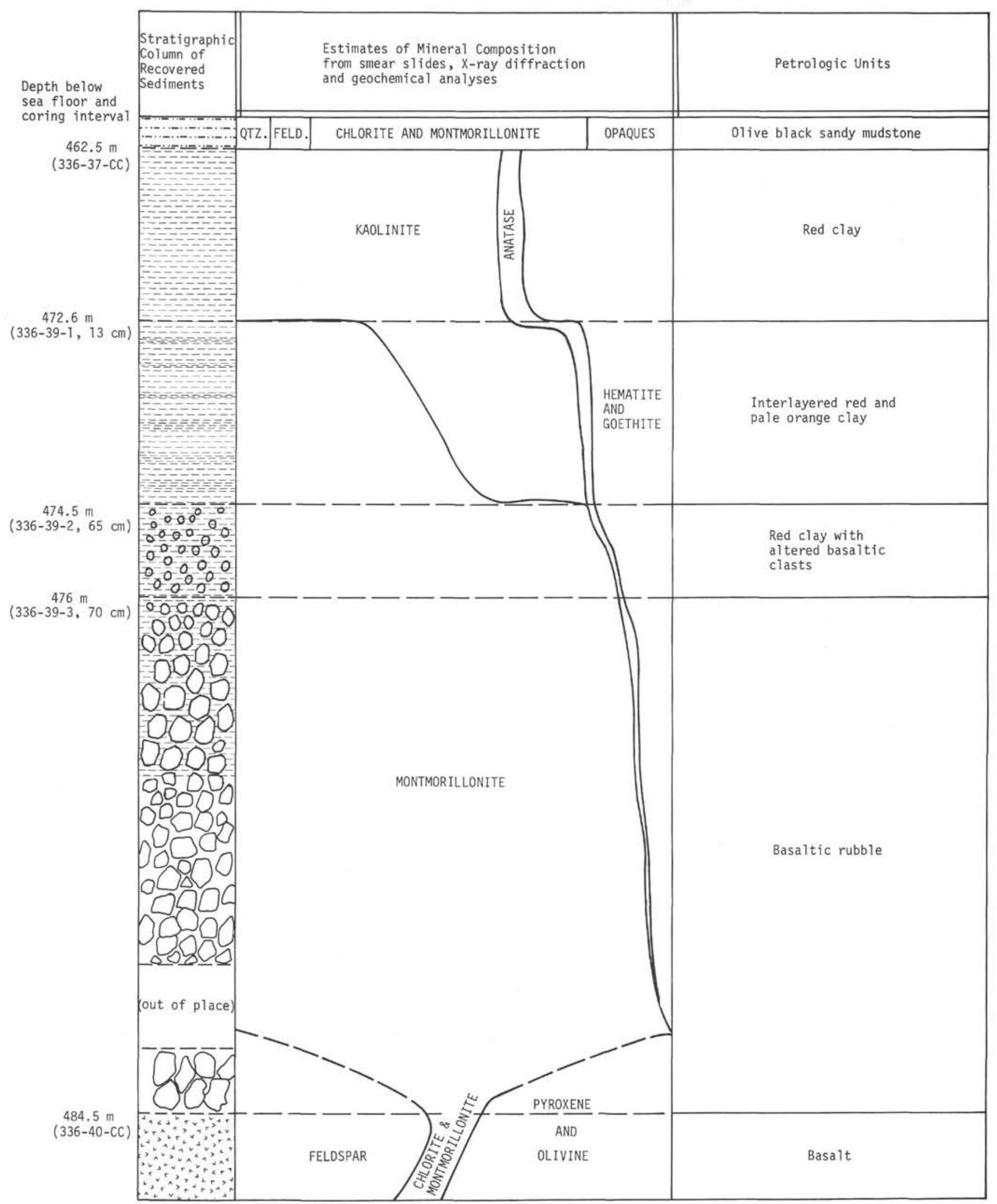

Figure 16. Stratigraphy and mineralogy of redbed sequence, Site 336.

ment into various patterns and shapes. The structures are also known as ichnofossils or lebenspur, and commonly take the form of tracks, trails, burrows, tubes, borings, and tunnels that record the life activities of the benthonic organisms. They are most easily recognized near color or texture boundaries, where differently 


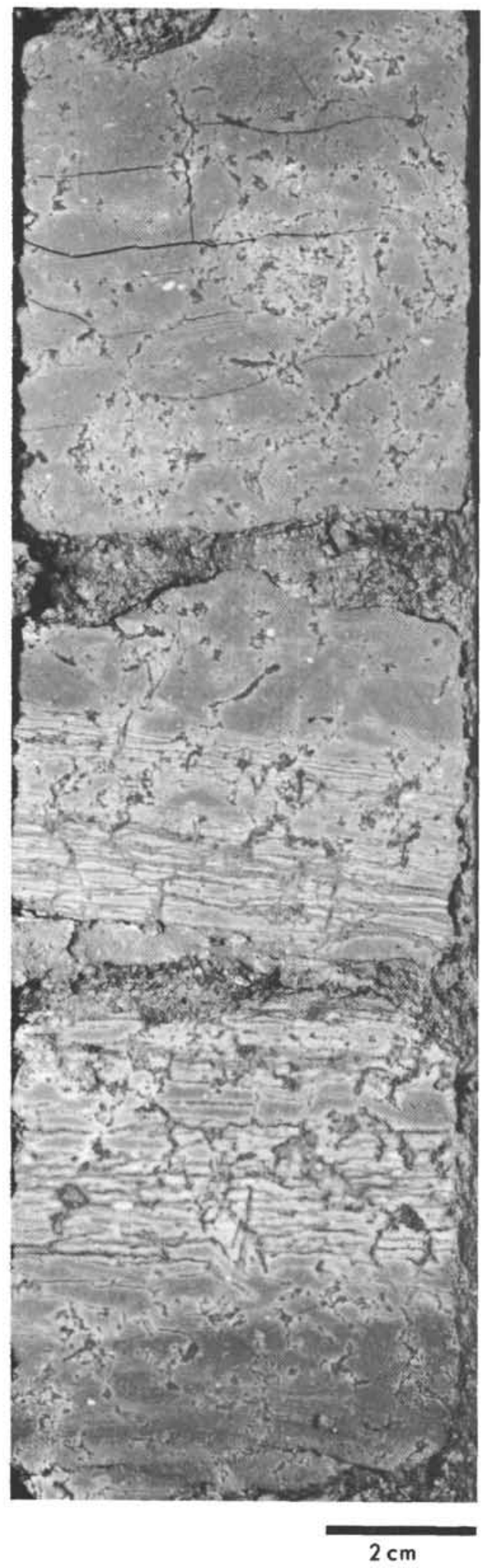

Figure 17. Interlayered red and pale orange clay unit, 336-39-1, 124-126 cm. Note pale orange interval with prominent root-like structures $(136-143 \mathrm{~cm})$, scattered white "clasts" $(129 \mathrm{~cm}$ and 144 $\mathrm{cm})$, and more massive red clay intervals $(124-136 \mathrm{~cm}$ and $144-146 \mathrm{~cm})$. colored or textured sediment is displaced upward and downward across the boundaries. Bioturbation, on the other hand, is simply defined as the churning and stirring of sediments by organisms, without necessarily leaving recognizable forms.

Well-indurated and lithified sediments generally contain the best suites of trace fossils; in DSDP cores, the best preserved trace fossils can be seen in the lower, more consolidated and older sequences at each drilling site. Sediments from the uppermost 100-200 meters at each site of Leg 38, for example, are generally characterized by abundant color mottling but a lack of recognizable trace fossils. Because coring deformation is also generally strong in these upper sediments, it is usually difficult if not impossible to ascribe with certainty the color mottling to bioturbation. In many cases, the mottling and homogenization of sediment may be caused by intermixing of sediments as they enter the core barrel, and further mixing as the sediments move up the length of the core barrel; expulsion of fluids and expansion of gases within the sediment when the cores are brought onboard the ship and opened may also cause mottling and homogenization of the sediments.

Trace fossils, mottling, and the extent of core deformation were routinely recorded by Leg 38 sedimentologists during examination of split cores. Identification of trace fossils followed the manual prepared by Chamberlain (1973) for DSDP. Recognition of trace fossils is limited, as is that of sedimentary structures, by the narrow width of the split cores and sampling limitations; thus, very large trace fossils, the lateral variation in distribution of trace fossils, and the orientational characteristics of trace fossils are difficult to observe.

The trace fossils preserved in the cores of deep-ocean sediments are almost wholly those produced by the burrowing activities of infaunal invertebrates. Because sedimentation rates are generally very slow, the sediment substrata is thoroughly reworked, and surficial features, such as trails and grazing traces on the ocean floor, are eventually destroyed. Even if preserved locally, they will not be observed very well in the cores because stratification surfaces cannot normally be seen.

\section{Previous Studies of Deep-Sea Trace Fossils}

Bioturbation of sediments and sedimentary rocks has been noted and described in varying detail from almost every previous leg of the Deep Sea Drilling Project. More detailed studies and analyses have been published and are listed in the reference section.

Studies of bioturbation and trace fossils from modern shallow marine, shoreline, lacustrine, and fluvial environments are too numerous to list herein, as are studies of bioturbation from rocks of various ages that are found on land (Frey, 1975). Needless to say, a great variety of trace fossils have been studied in onland exposures, and many have subsequently been recognized in deep-sea cores. The combination of trace fossil studies from modern and ancient depositional environments has resulted in the establishment of ichnofacies, which are sedimentary facies characterized by similar trace fossils or assemblages of trace fossils 
(Seilacher, 1967). These ichnofacies may reflect deposition in particular depths of water, at particular rates of sedimentation, of particular types of sediments or other factors.

\section{Descriptions of Trace Fossils}

\section{Introduction}

Most of the trace fossils recognized in Leg 38 cores are long ranging and have previously been recognized in deep-sea cores and rocks from many localities. Names of trace fossils in general adhere to the rules of the International Commission on Zoological Nomenclature, although the taxa are not recognized as being formally valid. The names are prefixed with the term Ichno, which identifies them as trace fossils rather than the remains of skeletal or other hard parts.

\section{Chondrites}

The ichnofossil Chondrites (Ichnogenus Chondrites Sternberg, 1833) consists of a central vertical shaft with numerous primary and secondary branches that are regular in shape, horizontal to inclined, branched at particular angles, and of equal width (Figure 18a, b). Chondrites has been described in great detail by Simpson (1967), Kennedy (1970), and Frey and Howard (1970).

Chondrites is the trace of a deposit-feeding, vermiform organism of unknown affinities that apparently engaged in a systematic downward search for nutrientrich sediment. Where thin, nutrient-rich laminae were located, the systematic search pattern was replaced by a more concentrated program of lateral mining. Simpson (1957) concluded that the animal lived on or just below the sediment floor at a fixed locale and dug tunnels downward with the aid of an extensible proboscis-like organ. Modern sipunculoid worms most closely resemble the type of animal that would generate Chondrites (van der Lingen, 1973). Chondrites is found in a variety of widely scattered marine sediments and sedimentary rocks that range in age from Cambrian to Tertiary.

Chondrites is commonly found in reworked larger burrows, in many cases as smaller tubes that makke up the secondary tubes in composite burrows (Figure 18d). The reworked sediments of the older or larger burrows are probably richer in nutrients, better oxygenated, and more easily perforated by the burrowing animal (Warme et al., 1973). Ekdale (1974) concluded that Chondrites is the deepest trace fossil in the deep-sea assemblage, that the Chondrites-producing organism commonly burrowed as deeply as $20 \mathrm{~cm}$ below the sediment surface, and that Chondrites is more characteristic of biologic oozes than terrigenous sediments.

Chondrites is one of the most common and widespread trace fossils observed in Leg 38 cores, in terms of both the age and lithology of the sediments within which it was found (Table 2).

There is no apparent preference of Chondrites for terrigenous or biogenic sediments, and it occurs in sediments of upper Eocene to Pleistocene age. It is not found in turbiditic sediments, and the reasons why it was not observed in Holes 346 to $352 \mathrm{~A}$ are not clear, although it was noted in a mudstone rip-up clast in an upper Eocene pebbly mudstone sequence at Site 349 (Figure 18e).

\section{Composite Burrows}

Composite burrows consist of a large tubular burrow, $2-5 \mathrm{~cm}$ across, containing one or more different small burrows, such as Helminthoida or Chondrites, and (or) fecal pellets within the larger structure (Chamberlain, 1973). Planolites and Zoophycos commonly form the larger structure in composite burrows, which develop because the burrow infilling apparently contains substantial nutrient value. The occurrences of composite burrows are noted in Table 2 .

Each of the terrigenous sequences listed contains some thin turbidite intervals; the locations include the Lofoten Basin, Jan Mayen Ridge, and a ridge south of and aligned with the Jan Mayen Ridge. Planolites forms the larger structure in Figure 19a, and may also be the larger structure in Figure 19b, c, in which the mudstone is deformed by numerous minor shears, thus possibly obscuring the original ellipsoidal character of the burrow; Chondrites is probably the smaller trace fossil in each case.

\section{Halo Burrows, Rind Burrows, Planolites, and Cylindrichnus}

Halo burrows range from 1 to $4 \mathrm{~cm}$ across and contain a halo of light material around or through the tube, with the color change gradational over a distance of 3 to $20 \mathrm{~cm}$ (Figure 20a); the halos are thought to have developed diagenetically as a result of organic materials left by the burrowing animals (Chamberlain, 1973). Rind burrows are cylindrical or subcylindrical burrows that contain a light colored outer layer and a darker colored center (Figure 20b); they also range from 1 to 4 $\mathrm{cm}$ across and appear to be most common in red muds (Chamberlain, 1973).

The above-described two trace fossils were systematically recorded in Leg 38 cores, inasmuch as Chamberlain's (1973) system was used. Many of these forms, however, can probably be ascribed to Planolites and Cylindrichnus.

The trace fossil Planolites (Ichnogenus Planolites Nicholson, 1873) is a smooth-walled, unbranched, cylindrical or subcylindrical, sediment-filled tunnel 5$10 \mathrm{~mm}$ in diameter; it is primarily horizontal in orientation and contain no internal structure or external surface sculpture (Ekdale, 1974). In DSDP cores, Planolites ranges in age from Lower Cretaceous to Pliocene and is one of the most common trace fossils, being most abundant in nannofossil oozes (Ekdale, 1974). Planolites is normally darker than the surrounding sediments and may be surrounded by darker or lighter colored halos. It commonly forms composite burrows, being filled later by Chondrites. Planolites is a feeder burrow thought to be formed by a depositfeeding worm or infaunal holothuroid as it moved horizontally through the sediment in a straight line.

The trace fossil Cylindrichnus (Ichnogenus Cylindrichnus Ekdale, 1974) was proposed for subhorizontal, straight or gently curved, tubular burrows that are roughly subcircular in cross-section and range from 1 to $3 \mathrm{~cm}$ across. It is considered by Ekdale (1974) to be the most widespread trace fossil in DSDP cores, and in 


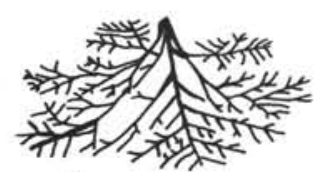

A
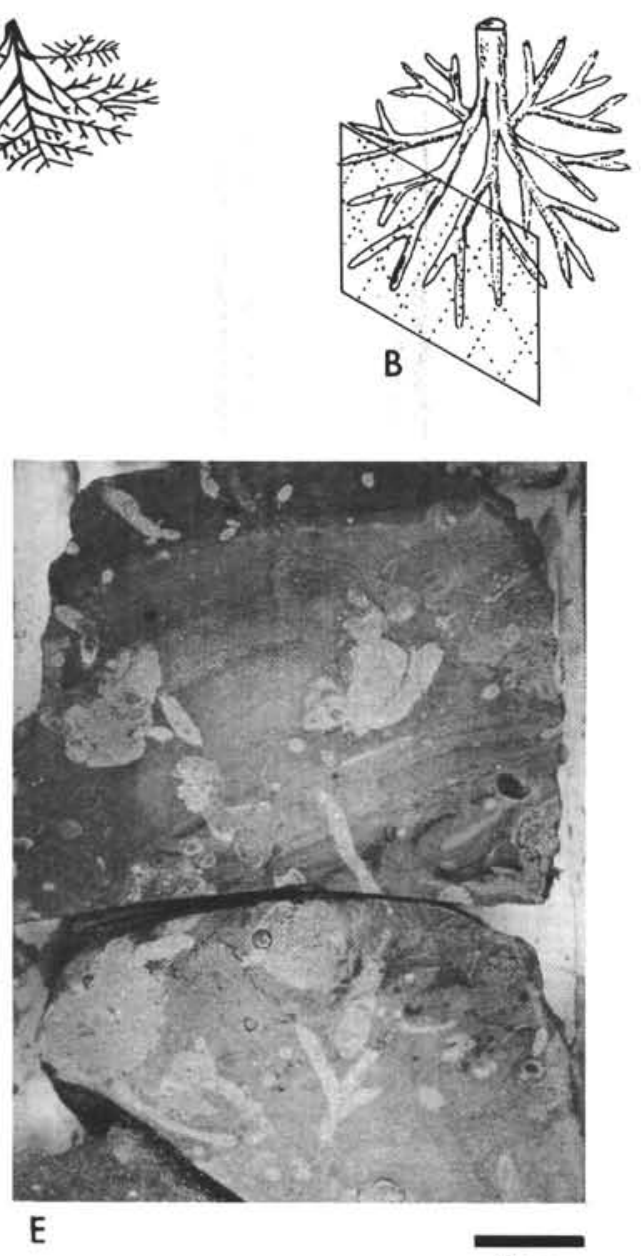
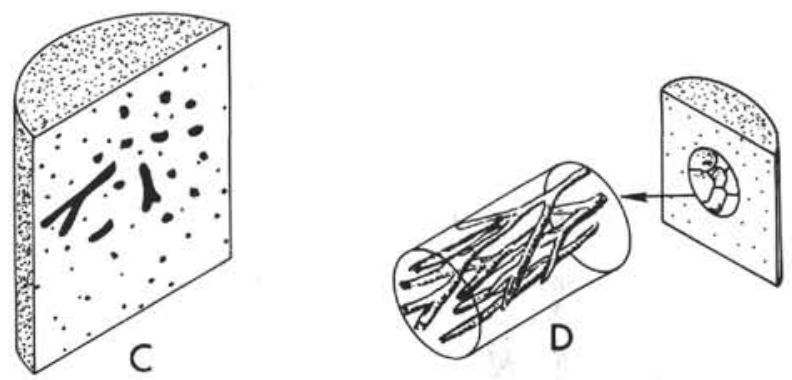

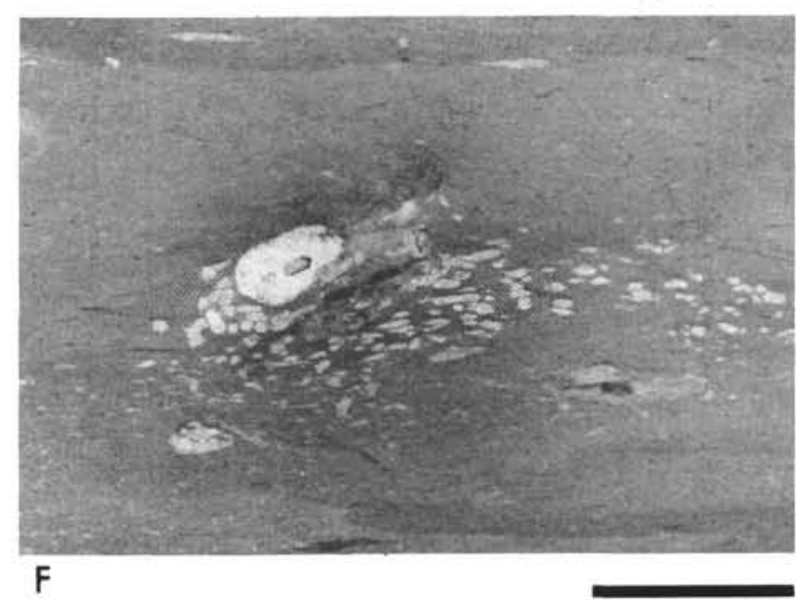

$1 \mathrm{~cm}$

Figure 18. Diagrammatic sketches and photographs of Chondrites. (a) Idealized sketch (modified by Warme et al., 1973, fig. 1A, from Simpson, 1957, p. 484). (b) Idealized sketch with vertical planar section (from Chamberlain, 1973, fig. 55B). (c) Idealized sketch in split core (from Chamberlain, 1973, fig. 55A). (d) Composite burrow within which is secondary Chondrites (from Chamberlain, 1973, fig. 55C). (e) Chondrites in mudstone clast in upper Eocene pebbly mudstone, 349$10-3,115 \mathrm{~cm}$. (f) Chondrites in Oligocene mudstone, 345-21-1, $5 \mathrm{~cm}$; also note Halo burrows with dark centers in upper left and lower right, small composite burrow in lower left, and pseudoparallel lamination. The Halo burrows may be Cylindrichnus hollowus.

contrast with Planolites, is circular rather than ellipsoidal in cross-section, rarely completely horizontal in orientation, and is generally filled with sediment that is lighter than the surrounding sediment. It has two forms, hollow and solid, considered ichnospecies by Ekdale (1974). The two forms commonly are found together, but rarely in association with Planolites, Zoophycos, or Chondrites. They are thought to be wandering feeding trails formed by a large infaunal worm or holothuroid; diagenesis of a chemical residue or mucus slime causes the whitening of the sediment, and different stages of diagenesis are responsible for the two forms (Ekdale, 1974). Cylindrichnus ranges in age from Early Cretaceous to Pleistocene in DSDP cores and is most common in red clays.

Planolites and Cylindrichnus were not recorded onboard Glomar Challenger during Leg 38, but subsequent examination of core photos and core descriptions indicates that they are both common. Unfortunately, their overall distribution is not known.

Halo burrows were observed in five sections of Oligocene to late Eocene mudstone and sandy mudstone at Site 345, from Sections 15-1 to 25-3 (Figure 20c). Some thin sandy turbidites are present in the lower part of this sequence, although the burrows are found in interlayered mudstones. Halo burrows, recognizable as Cylindrichnus hollowus, are also present in middle Oligocene nannofossil ooze from Hole 352A, Section 3-2 (see Figure 20g).

Rind burrows are present in sediments from five holes (Table 2). The Rind burrows seem to be restricted to pre-Miocene sediments and to primarily terrigenous sediments, although geographically they are widely distributed in the Norwegian-Greenland Sea area.

Planolites was clearly recognized in photos of Oligocene mudstone at Site 345 (see Figures 20c, 20d, 
TABLE 2

Occurrences of Trace Fossils in Leg 38 Cores

\begin{tabular}{|c|c|}
\hline Site & Remarks \\
\hline \multicolumn{2}{|r|}{ Chondrites } \\
\hline 336 & Upper Eocene - mud/claystone \\
\hline 338 & $\begin{array}{l}\text { Pliocene or Pleistocene muddy calcareous } \\
\text { ooze to lower Eocene to M. Oligocene - } \\
\text { diatom ooze, nannofossil ooze, mudstone, } \\
\text { sandy mudstone }\end{array}$ \\
\hline 339 & Pleistocene - calcareous mud and mud \\
\hline 341 & $\begin{array}{l}\text { Middle to upper Miocene - mudstone, } \\
\text { diatomaceous mudstone, and diatomaceous } \\
\text { ooze }\end{array}$ \\
\hline 343 & "Glacial" - muds \\
\hline 344 & $\begin{array}{l}\text { Miocene or Pliocene - mudstone, sandy } \\
\text { mudstone }\end{array}$ \\
\hline 345 & Oligocene - mudstone (See Figure 18f) \\
\hline \multicolumn{2}{|l|}{ Site, Core, Section } \\
\hline & Composite Burrows \\
\hline $345,11-5$ to $23-2$ & Oligocene - mudstone (See Figure 19) \\
\hline $346,15-2$ to $20-1$ & $\begin{array}{l}\text { Pre-middle Miocene - mudstone/sandy } \\
\text { mudstone }\end{array}$ \\
\hline $347,4-1$ & Pre-"glacial" - sandy mudstone \\
\hline $348,20-6$ & Pre-middle Miocene - mudstone-claystone \\
\hline $350,14-1$ & Upper Eocene - mudstone \\
\hline Site & Remarks \\
\hline \multicolumn{2}{|r|}{ Rind Burrows } \\
\hline 336 & Middle-upper Eocene - mudstone \\
\hline 338 & Lower Eocene - mudstone sandy mudstone \\
\hline 341 & $\begin{array}{l}\text { Middle to upper Miocene - calcareous diatom- } \\
\text { ite, calcareous diatomaceous mudstone }\end{array}$ \\
\hline 345 & Oligocene - mudstone, sandy mudstone \\
\hline 348 & $\begin{array}{l}\text { Pre-early Miocene - mudstone, sandy mud- } \\
\text { stone mudstone }\end{array}$ \\
\hline Site & Remarks \\
\hline \multicolumn{2}{|r|}{ Helminthoida } \\
\hline 336 & Upper Eocene - mudstone \\
\hline 338 & Lower Eocene - mudstone, limestone \\
\hline 341 & $\begin{array}{l}\text { Middle and upper Miocene - diatomaceous } \\
\text { sediments }\end{array}$ \\
\hline 343 & "Glacial" - calcareous ooze \\
\hline 344 & Miocene and Pliocene - mudstone \\
\hline 345 & Oligocene - mudstone \\
\hline 346 & Pre-middle Miocene - mudstone \\
\hline 348 & Pre-Miocene - mudstone \\
\hline Site & Remarks \\
\hline \multicolumn{2}{|r|}{ Zoophycos } \\
\hline 338 & $\begin{array}{l}\text { Early to late Eocene - diatom ooze and } \\
\text { mudstone }\end{array}$ \\
\hline 341 & $\begin{array}{l}\text { Middle to late Eocene - mudstone, diatom- } \\
\text { aceous sediments }\end{array}$ \\
\hline 345 & $\begin{array}{l}\text { Oligocene - sandy mudstone, mudstone } \\
\text { (turbidites) }\end{array}$ \\
\hline 348 & Pre-early Eocene - mudstone \\
\hline
\end{tabular}

and 20e). Cylindrichnus, both forms, were recognized in photos of Oligocene nannofossil ooze in Hole 353A (see Figure 20f, g).
TABLE 2 - Continued

\begin{tabular}{|c|c|}
\hline Site, Core, Section & Remarks \\
\hline \multicolumn{2}{|c|}{ Noncalcareous Worm Tubes } \\
\hline $345,21-2$ to $31-6$ & $\begin{array}{l}\text { Oligocene and late Eocene - mudstone, } \\
\text { sandy mudstone (See Figures } 2,5 \text { ) }\end{array}$ \\
\hline $346,14-3$ to $17-2$ & $\begin{array}{l}\text { Pre-middle Miocene - mudstone, sandy } \\
\text { mudstone }\end{array}$ \\
\hline $347,4-1(?)$ & $\begin{array}{l}\text { Pre-"Glacial" - sandy mudstone and } \\
\text { claystone }\end{array}$ \\
\hline $348,26-1$ to $32-3$ & $\begin{array}{l}\text { Pre-middle Miocene - mudstone, sandy } \\
\text { mudstone }\end{array}$ \\
\hline $350,10-3$ & Oligocene - mudstone \\
\hline
\end{tabular}

\section{Helminthoida}

The ichnofossil Helminthoida (Ichnogenus Helminthoida Schafhäutl, 1851) consists of numerous, smooth, parallel, and equidistant concentric furrows about $2 \mathrm{~mm}$ wide (see Figures 21a, b). It is associated with Helminthopsis, which consists of simple meandering tracks that are not as strictly developed as Helminthoida (Figures 21c, d) and is recognized in cores as cross-sections and loop-ends of a series of paired tubes along the same lamination (Figure 21e). It ranges in age from Cretaceous to Tertiary (Hantzschel, 1962).

Helminthoida was thought to have been recognized in numerous cores. It appears to have a widespread distribution in sediments of different age, different lithology, and from diverse localities (Table 2).

\section{Teichichnus}

The ichnofossil Teichichnus (Ichnogenus Teichichnus Seilacher, 1955) is a trough-like system of spreite, probably a $\mathrm{U}$-shaped tube produced by the upward migration of consecutive horizontal burrows in the same vertical plane (Figure $22 \mathrm{a}, \mathrm{b}, \mathrm{c}$ ). It appears in deep-sea cores as a vertical stack of concave-up backfill structures that are sometimes pelleted and range from $5-15 \mathrm{~mm}$ in width and $2-15 \mathrm{~cm}$ in height. However, it consists of many different forms that are generally lumped together under a single unnamed ichnospecies. It ranges from lower Cambrian to Tertiary (Hantzschel, 1962) and has been observed in deep-sea cores ranging in age from Lower Cretaceous to Pliocene, being most common in biogenic oozes from the Caribbean Sea and Indian and Pacific oceans (Ekdale, 1974). The Teichichnus-producing organism is probably a relatively shallow burrower, perhaps one that migrated upward with sedimentation, so that the last tube occupied is the topmost.

Teichichnus was clearly recognized in an Oligocene mudstone from the Lofoten Basin in 345-21-6 (Figure $22 \mathrm{~d}$ ) and doubtfully recognized in a pre-middle Miocene (Eocene) sandy mudstone from the Jan Mayen Ridge in 346-20-1. Both sedimentary sequences contain some thin interlayered turbidites, and are clearly not of biogenic origin.

\section{Zoophycos}

The ichnofossil Zoophycos (Ichnogenus Zoophycos Massalongo, 1855) consists of circular or lobate sheet- 


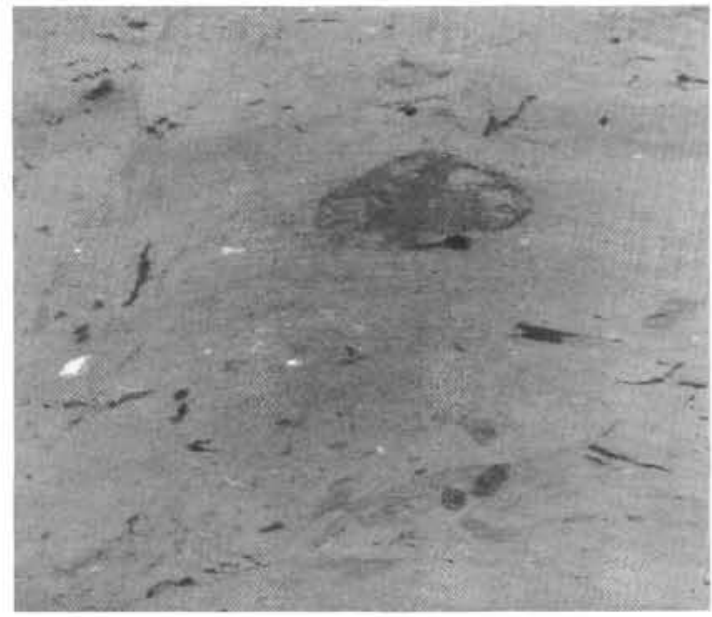

A

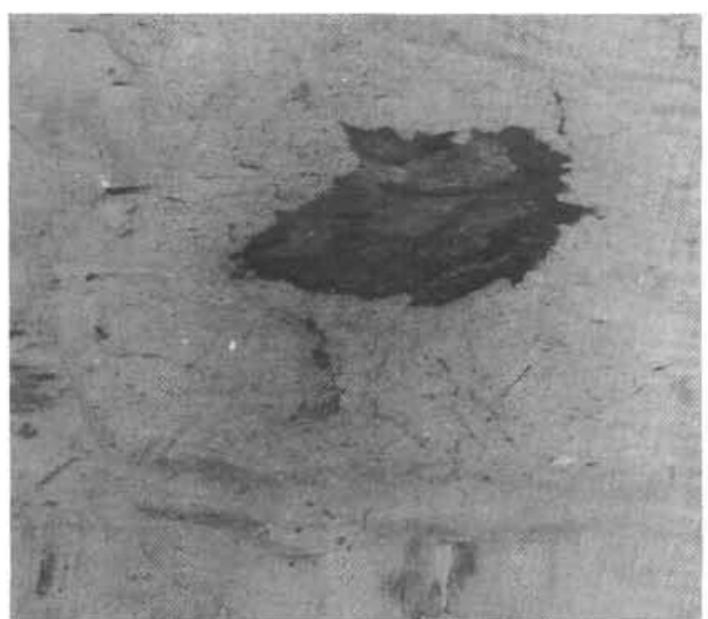

B

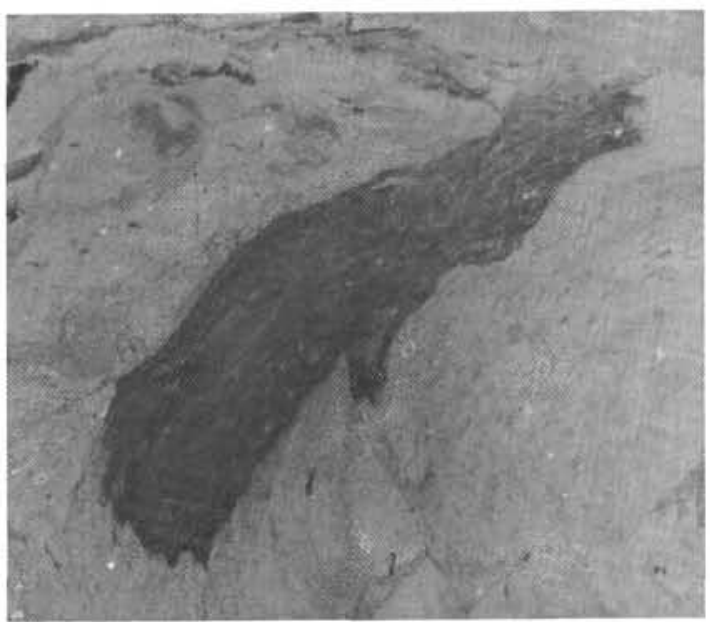

C

Figure 19. Composite burrows in Oligocene mudstones of Hole 345, Lofoten Basin. (a) Planolites filled with Chondrites, Sample 11-5,54 cm. (b) Possibly sheared Planolites probably filled with Chondrites, Sample 11-6, $145 \mathrm{~cm}$. (c) Possibly large sheared Planolites, filled with Chondrites, Sample 11-6, 26-36 cm.

like spreite, either flat, curved, inclined, or wound in a screw-like fashion around a central vertical axis (Figure $23 \mathrm{a}, \mathrm{b}, \mathrm{c}, \mathrm{d})$. It appears in cores as horizontal or subhorizontal parallel burrow tunnels, with each tunnel representing the path of the organism during a single probing of the sediment. Each horizontal tunnel is filled by lunate, concave-out backfill structures marked by fecal material excreted by the animal.

Zoophycos has been noted in Ordovician and Devonian to Tertiary strata (Hantzschel, 1962) and has been found in deep-sea cores of Upper Cretaceous to Holocene age (Ekdale, 1974). It takes many diverse forms, including simple, curved, fat, and pelleted (Ekdale, 1974, p. 62-68). The Zoophycos-producing animal is not known, although it must have had either a long, round, flexible body or a long feeding apparatus such as a probiscus. In Leg 38 cores, pelleted Zoophycos is the most common form (see Figure 23f, $\mathrm{g}$ ) and simple Zoophycos is also present (see Figure 23e). Fat and curved Zoophycos were not recorded.

Zoophycos was observed in four holes (Table 2). The great majority of occurrences of Zoophycos are in terrigenous mudstone, although it is also abundant in biogenic diatomaceous sediments. It was not recognized in post-Oligocene sediments.

\section{Pyritized Burrows}

Subcylindrical pyritized burrows, generally on the order of 3-10 mm in diameter and several centimeters in length, were noted frequently in Leg 38 cores. They were found in both vertical and horizontal positions and in most cases were noted in core descriptions as pyrite nodules rather than pyritized burrows (see previous section entitled Pyrite Nodules), because of uncertainties regarding their origin. Pyritized burrows have been occasionally found in DSDP cores, most commonly in nannofossil ooze, ranging in age from Upper Cretaceous to Pleistocene, from the Caribbean Sea and Atlantic and Pacific oceans (Ekdale, 1974). The pyrite probably replaced an original limonite cement within the burrows.

Pyritized burrows in Leg 38 cores, in contrast to previously collected DSDP data, are commonly subhorizontal in orientation and are found exclusively in 

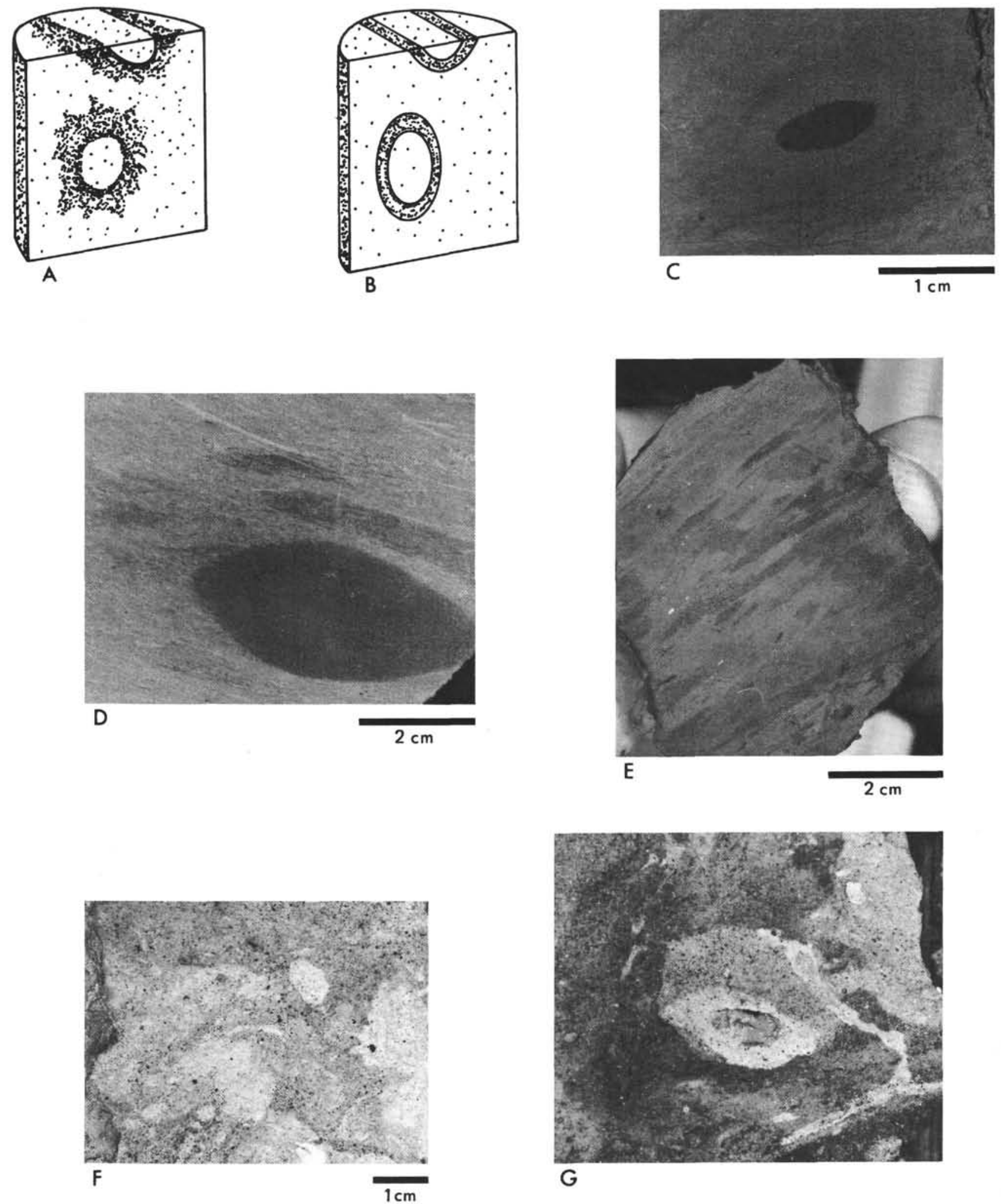

G

Figure 20. Diagrammatic sketches and photographs of Halo burrows, Rind burrows, Planolites, and Cylindrichnus. (a) Halo burrow (from Chamberlain, 1973, fig. 57A). (b) Rind burrow (from Chamberlain, 1973, fig. 57B). (c) Halo burrow from Oligocene mudstone, recognizable as Planolites, 345-15-1, $146 \mathrm{~cm}$. (d) Very large Planolites without halo from Oligocene mudstone, 345-21-2, $100 \mathrm{~cm}$. (e) Oligocene mudstone full of Planolites, 345-15-1, $84 \mathrm{~cm}$. (f) Cylindrichnus solidus, middle Oligocene nannofossil ooze, $352 \mathrm{~A}-3-2,108-117 \mathrm{~cm}$. (g) Cylindrichnus hollowus, a Halo burrow, from middle Oligocene nannofossil ooze, $352 A-3-2,46 \mathrm{~cm}$. 


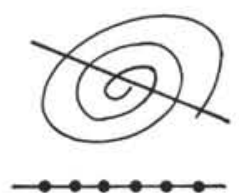

A

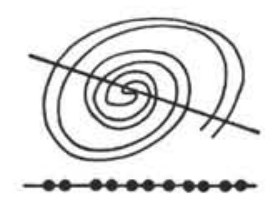

B

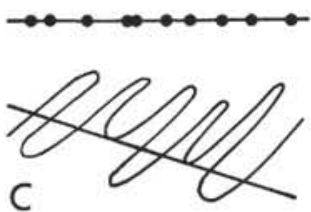

C

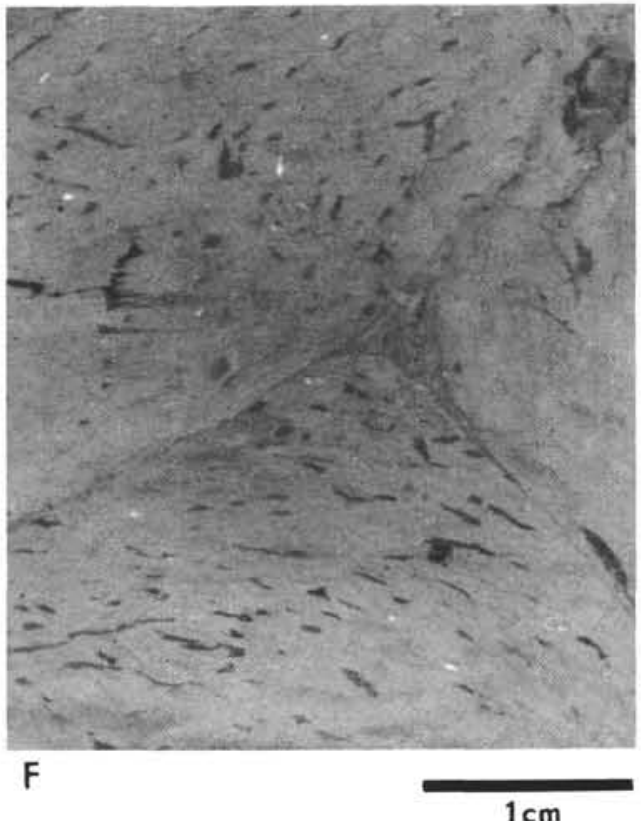

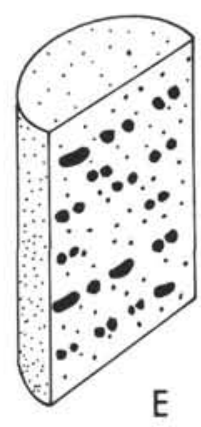

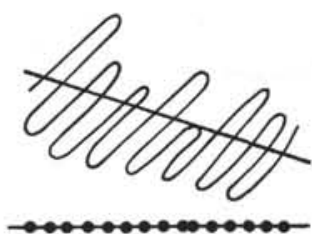

D

$E$

Figure 21. Diagrammatic sketches and photographs of Helminthoida. (a, b, c, d) Several hypotheses of loop and spiral arrangement of Helminthoida to explain appearance in split cores (from Chamberlain, 1973, fig. 56B, C, D, and E). (e) Helminthoida in split core cut transverse to loops (from Chamberlain, 1973, fig. 56A). (f) Helminthoida in brecciated and deformed upper Oligocene mudstone. $345-11-5,90 \mathrm{~cm}$.

mudstones and sandy mudstones of "glacial" to early Eocene age. They are present at Sites 338, 341, 343, 344, $345,346,347,348,349$, and 350 . They are particularly common at Site 348 in pre-lower Miocene mudstone and sandy mudstone. Many have a halo surrounding the burrow (Figure 11) and may represent filled Planolites.

\section{Noncalcareous Worm Tubes}

Worm tubes have been observed in sedimentary rocks ranging from early Paleozoic to Recent. However, they have not commonly been found in deepsea cores, and Ekdale (1974) notes only one occurrence, that of calcareous worm tubes in upper Paleocene sandstone from DSDP Leg 12 in the northeastern Atlantic. The tubes are constructed around themselves by worms through an agglutination process, so that the worms remain free to move in or out of them; the tubes may be calcareous or arenaceous, depending presumably upon the type of worm and type of sediment.

Noncalcareous worm tubes were found commonly in sediments at Sites 345,346 , and 348 , and rarely at Sites 347 and 350 (Table 2).

In common, all the worm tubes occur in terrigenous sediments that may all possibly be of Oligocene age, and in sequences with a few to abundant turbidite layers (see previous section on turbidite sequences). The localities include the Jan Mayen Ridge, a smaller ridge south of the Jan Mayen Ridge, and the Lofoten Basin.

None of the tubes were calcareous and they are invariably straight and cylindrical (Figure 24a). They range in diameter from 1 to $2 \mathrm{~mm}$ and in some cores are as long as $3 \mathrm{~cm}$ (Figure 24b). The great majority of tubes appear to be oriented horizontally or subhorizontally, locally subparallel to one another (Figure 24b), although some inclined tubes have been observed (Figure 24c).

\section{Miscellaneous Trace Fossils}

A significant number of well-preserved trace fossils in various cores could not be identified; in other cores, trace fossils were not well preserved and were noted in core descriptions as irregular burrows, bioturbation, burrow mottling, or in other vague terms. A particularly unusual and difficult-to-recognize suite of trace fossils was found in middle Oligocene calcareous oozes in Hole 352A, Core 3, Section 1 and Core 3, Section 2. Examples of these unidentified trace fossils are shown in Figure 25a, b. A number of other miscellaneous trace fossils were noted in Oligocene to late Eocene mudstones at Site 345, Cores 11 to 32 (see Figure 25c). 

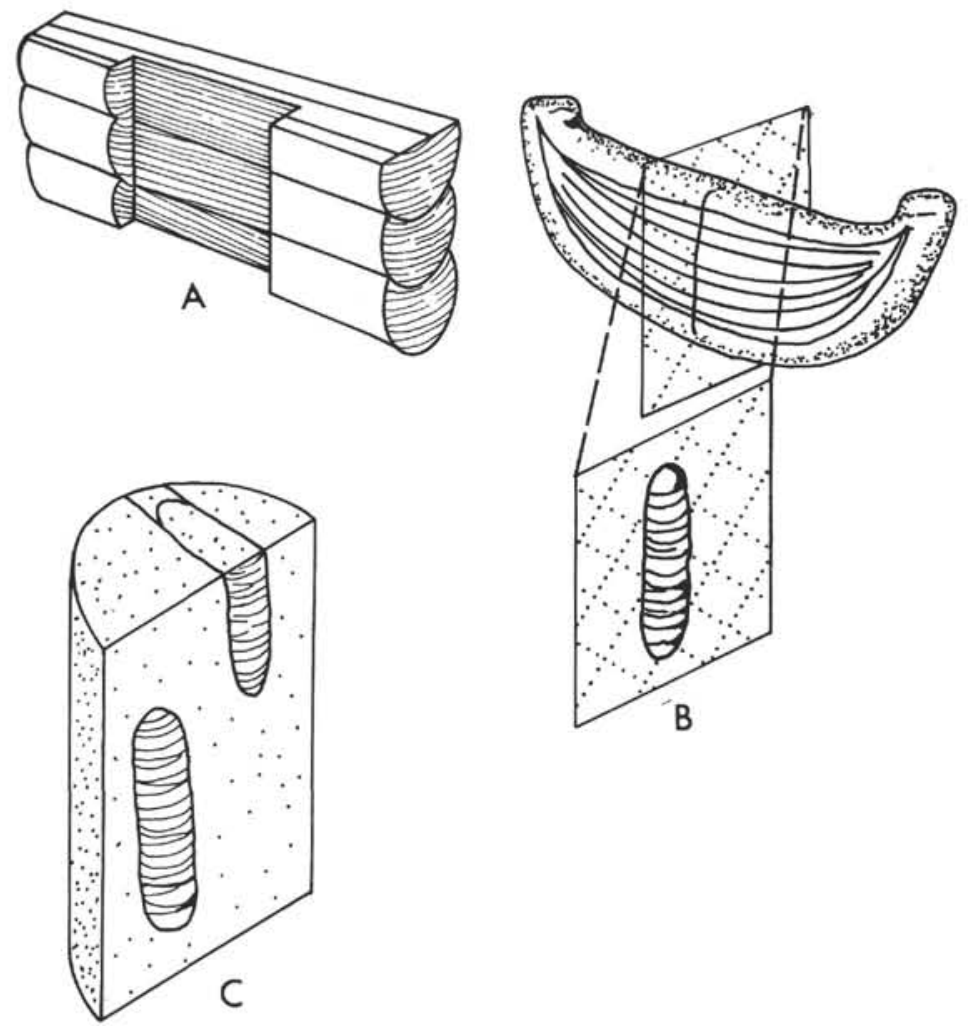

Figure 22. Diagrammatic sketches and photographs of Teichichnus. (a) Idealized sketch of Teichichnus showing possible arrangements of internal structure (from Warme et al., 1973, fig. 1B). (b) Diagrammatic sketch of an idealized Teichichnus and vertical planar section (from Chamberlain, 1973, fig. 68B and 58C). (c) Idealized sketch of Teichichnus exposed in split core (from Chamberlain, 1973, fig. 58A). (d) Teichichnus in Oligocene mudstone, 345-21-6, $70 \mathrm{~cm}$.

\section{SUMMARY OF SEDIMENTARY HISTORY}

In rift-margin ocean basins such as the NorwegianGreenland Sea, sedimentation is influenced most strongly by the twin effects of continued subsidence of older ocean floor away from the active spreading ridge and by the progressive increase in distance from the active spreading of the marginal continental sediment source areas, as new oceanic crust forming at the spreading ridge adds to the overall width of the ocean basin. As a result of these effects, stratigraphic sequences in such ocean basins should, in general, record a progressive deepening of the site of sedimentation through time, particularly at those sites with a thick sedimentary cover deposited over a long period of time on older oceanic crust. The stratigraphic sequences situated on younger oceanic crust, which are generally thinner and include sediments deposited over shorter periods of time, should be finer grained and less terrigenous in character, because at the time of their deposition continental margins or sediment source areas, were already quite distant.

However, the Norwegian-Greenland Sea is not a simple rift-margin ocean basin (Figure 1). It is complicated by (1) the fact that the spreading ridge in the southern part of the sea has probably migrated or shifted westward at least twice, from the extinct Norway Basin axis to the Iceland Plateau and then to the presently active Iceland-Jan Mayen ridge axis; (2) large volcanic plateaus that have strongly influenced water circulation and sedimentation patterns developed, probably over mantle diapirs or hot spots, on the Iceland-Faeroe Plateau, Iceland, and probably the V $\phi$ ring Plateau; (3) the Jan Mayen Ridge, located in the central southern part of the Norwegian-Greenland Sea and probably a fragment of the East Greenland continental margin that was detached by the westward migration or jump in the location of the active spreading ridge, subdivided the area into several subbasins; (4) extensive fracture zones that form prominent ridges trending more or less perpendicular to the continental margins, which have probably strongly influenced sedimentation patterns; and (5) the direction of plate motion and location of the pole of rotation have changed during the course of the rifting apart of Greenland and Norway-Spitsbergen, causing a more complicated juxtaposition of oceanic geographic and tectonic elements.

Because the objective of virtually every hole drilled on Leg 38 was basement, and most sites were thus drilled on basement ridges and volcanic plateaus, a complete record of the stratigraphic development of the Norwegian-Greenland Sea sediment cover is lacking. The basement ridges, because they stood topographically high, are generally marked by thin sedimentary columns punctuated major unconformities, a lack of the turbidite sequences, and abundant biogenic sediments. Thus, only at Site 345 in the Lofoten Basin is there a fairly complete and continuous 


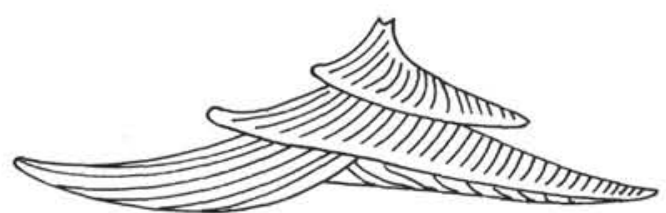

A
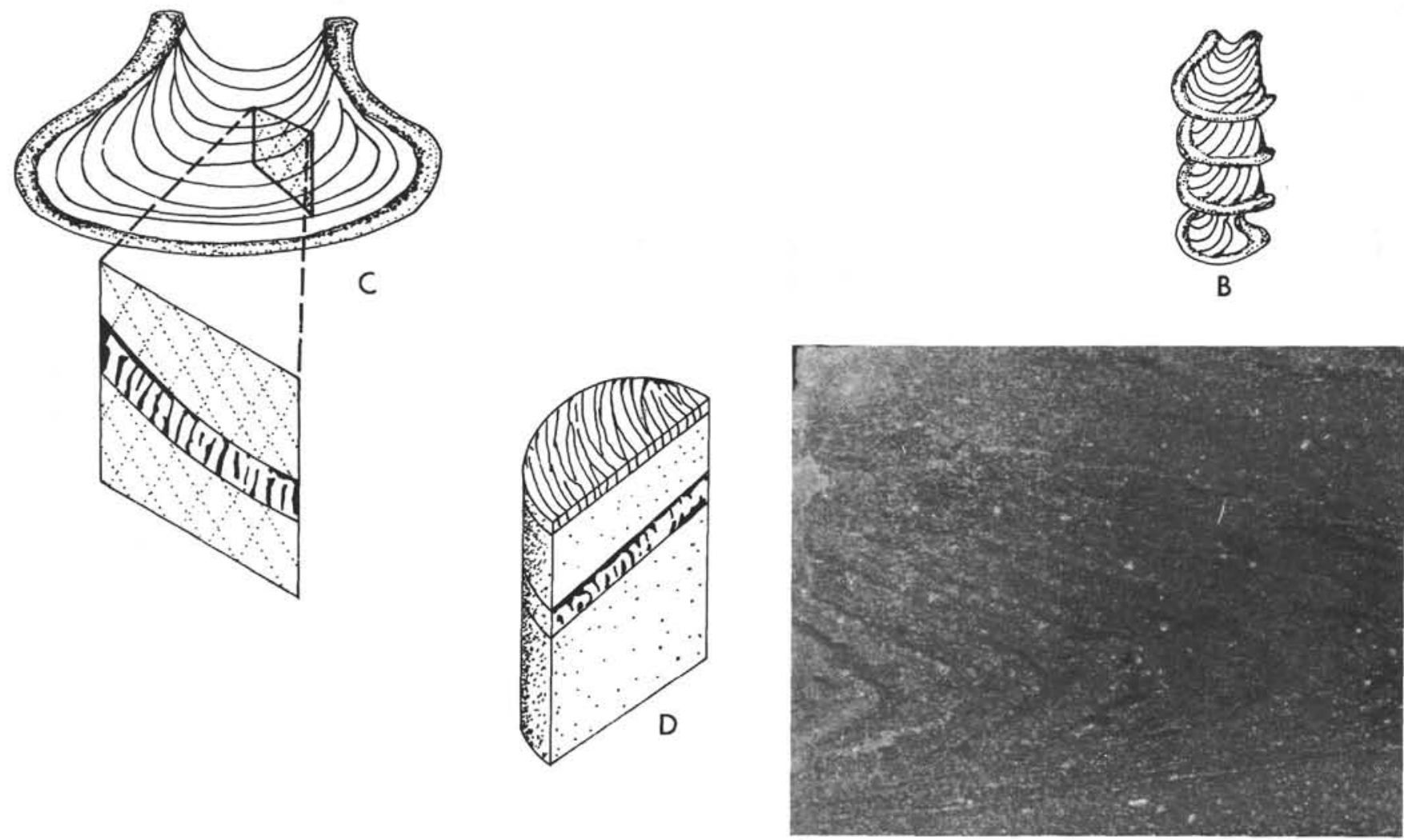

$\mathrm{E}$

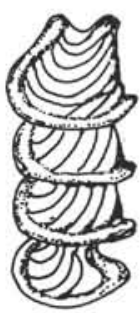

B

$1 \mathrm{~cm}$

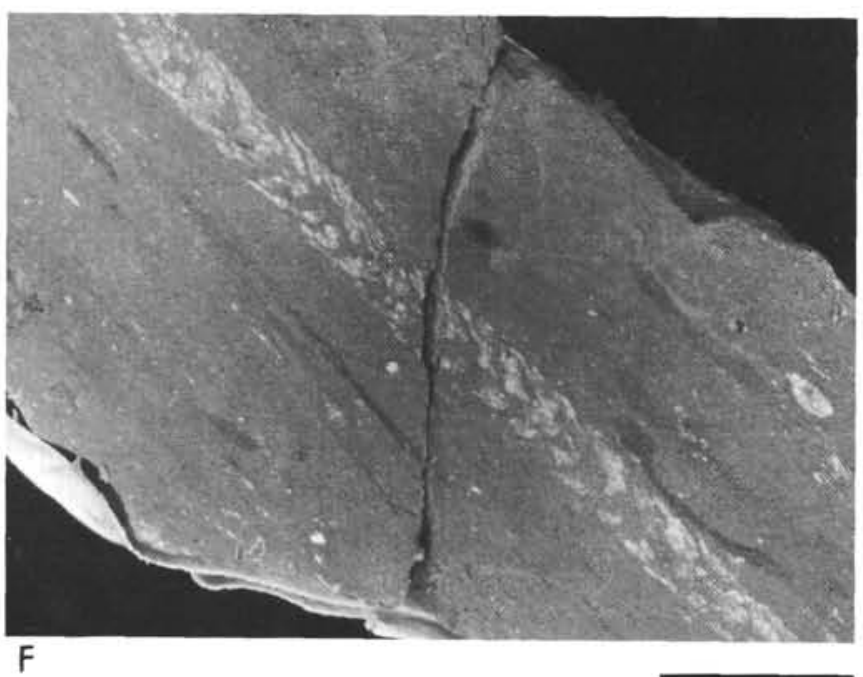

$1 \mathrm{~cm}$

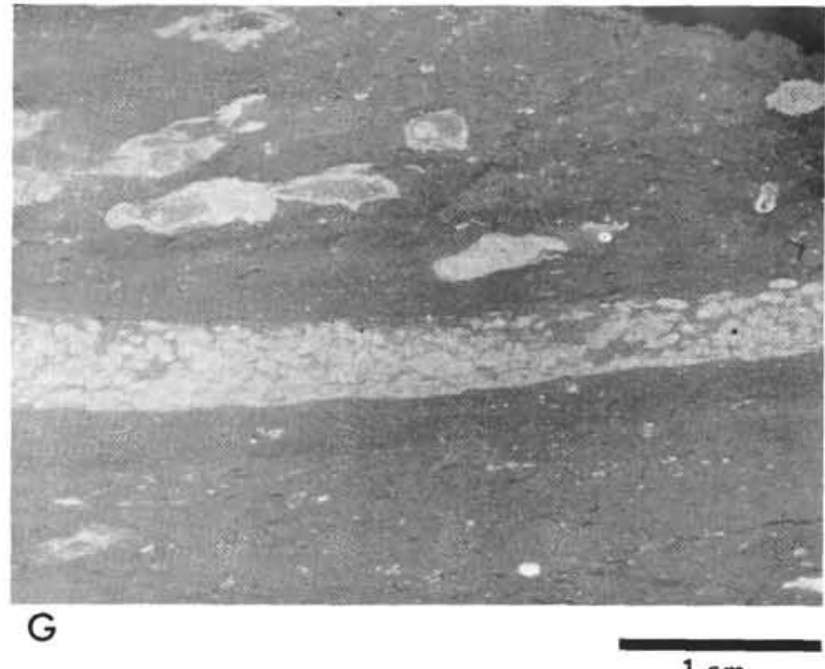

$1 \mathrm{~cm}$

Figure 23. Diagrammatic sketches and photographs of Zoophycos. (a) Sketch of Zoophycos (modified by Warme et al., 1973, fig. 1C from Hantzschel, 1962, p. W219). (b) Sketch of Zoophycos (from Chamberlain, 1973, fig. 58A). (c) Sketch of single loop of Zoophycos and vertical planar section showing meniscae of spreiten (from Chamberlain, 1973, fig. $58 \mathrm{C}$ and 58E). (d) Sketch of Zoophycos exposed in split core (from Chamberlain, 1973, fig. 58D). (e) Simple Zoophycos in Eocene(?) mudstone of 345-30-3, 118-120 cm. (f) Pelleted Zoophycos in Oligocene mudstone, 345-21-4, $38 \mathrm{~cm}$. (g) Extremely pelleted Zoophycos in Oligocene mudstone $345-21-4,41-45 \mathrm{~cm}$. 


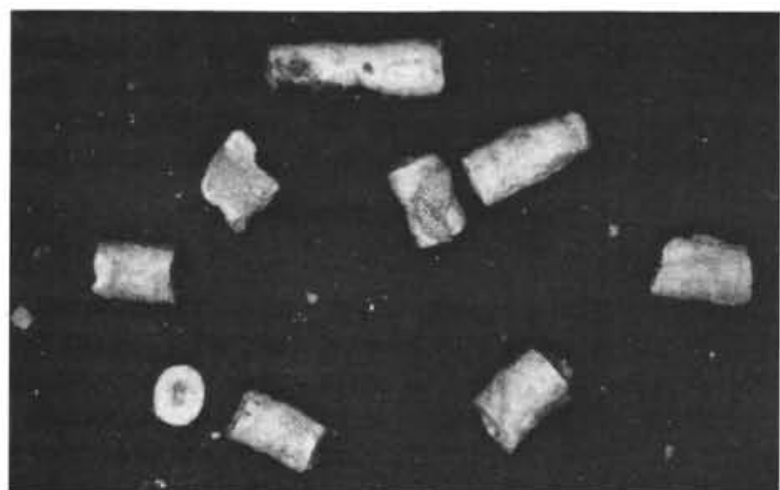

A

$1 \mathrm{~cm}$

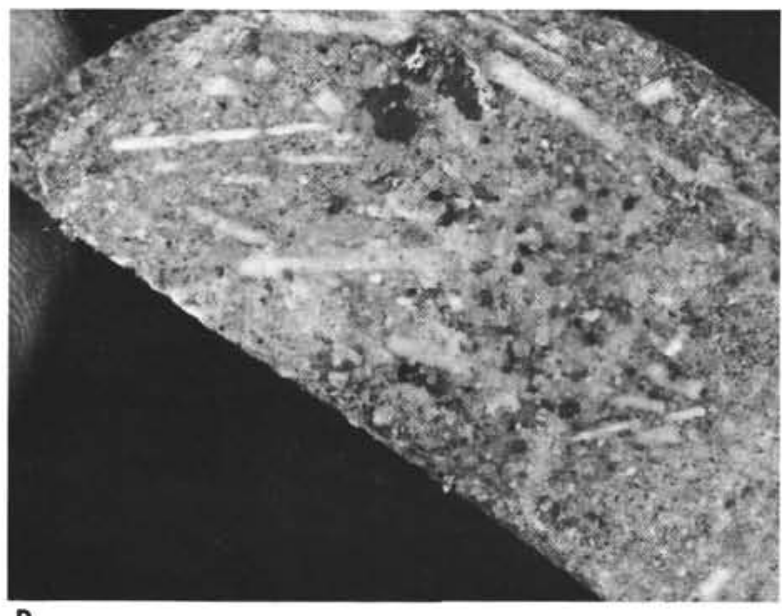

B

$1 \mathrm{~cm}$

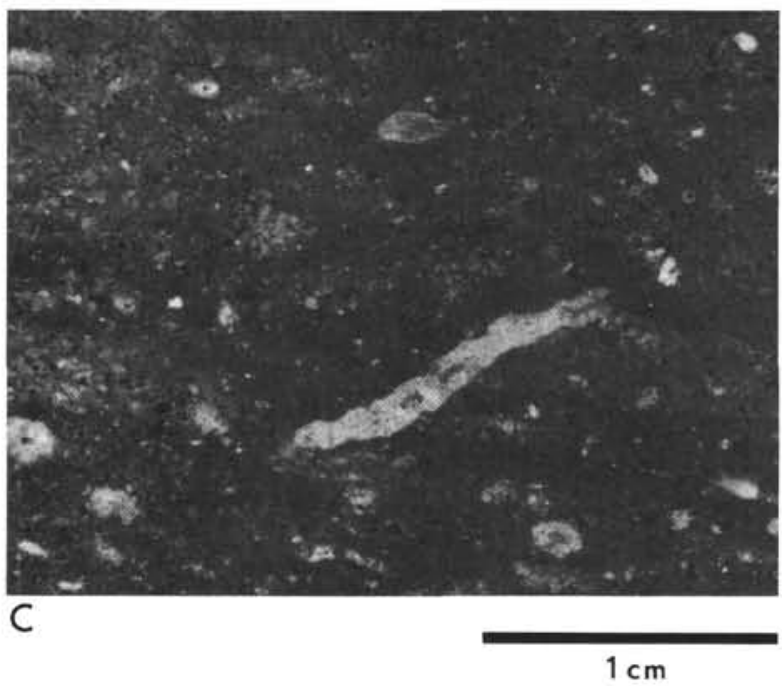

Figure 24. Worm tubes. (a) Tubes washed from Oligocene mudstone, 345-16, CC. (b) Tubes observed on layer surface of Eocene(?) sandy mudstone, 345-30-5, $72 \mathrm{~cm}$. (c) Inclined tube in sandy mudstone, 345-30$5,70 \mathrm{~cm}$.

record of the upward changes from nonmarine to turbidite to hemipelagic to biogenic to glacial sedimenta- tion. At Site 338 on the Vøring Plateau, a fairly complete sedimentary record of predominantly biogenic sedimentation from the early Eocene to the present is preserved, and at Site 344 near Knipovich Ridge, a

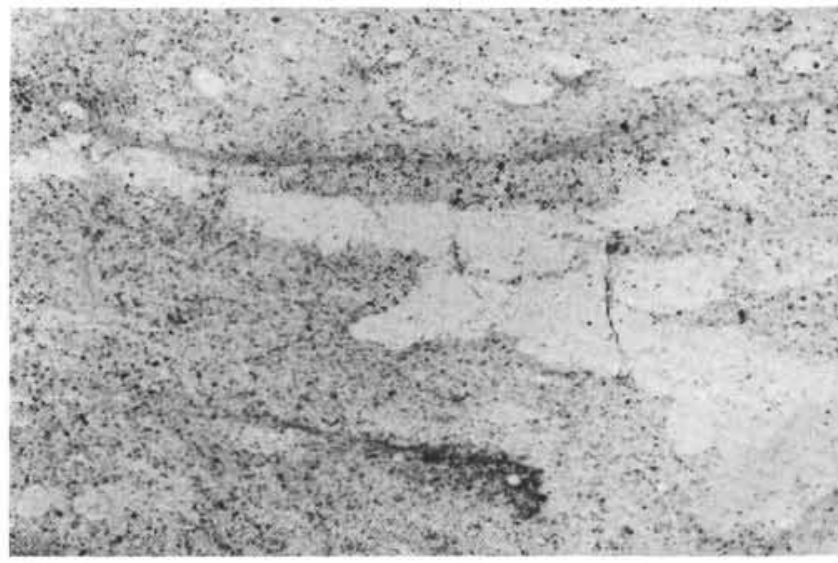

A

$1 \mathrm{~cm}$

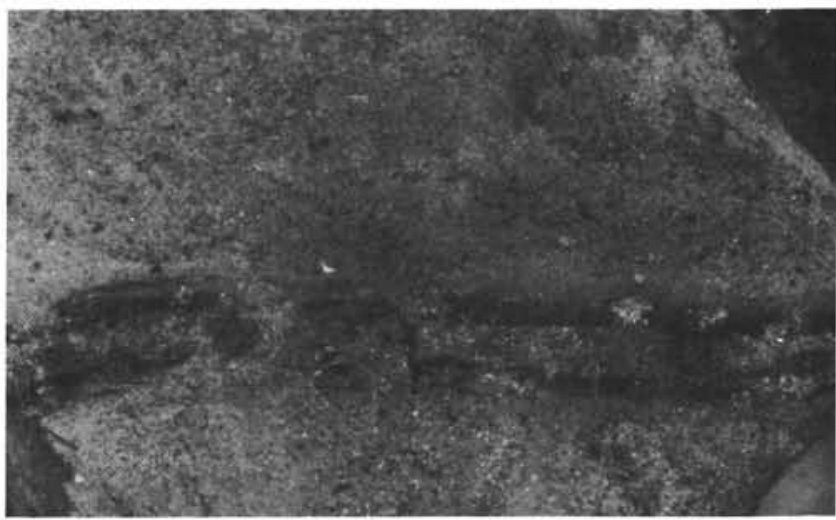

B

$1 \mathrm{~cm}$

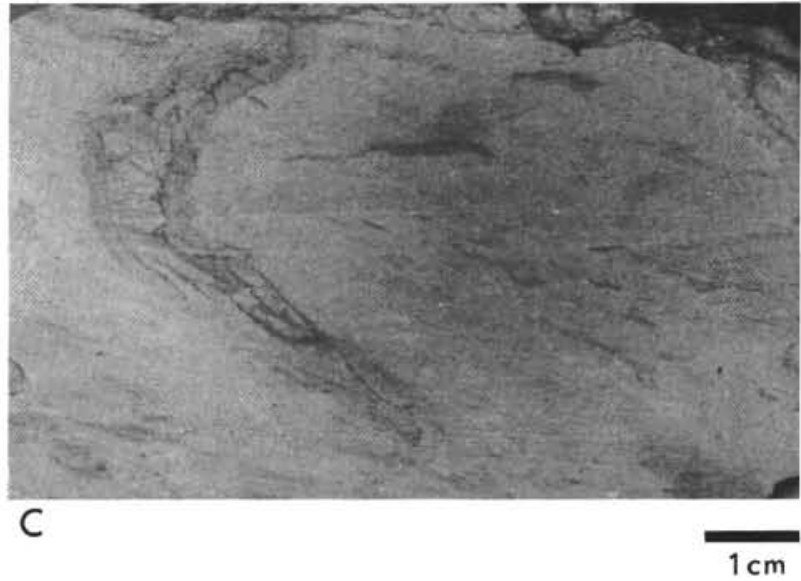

Figure 25. Miscellaneous trace fossils. (a) Irregularly shaped, branching, light colored trace fossils in ash-rich Oligocene nannofossil ooze, $352 \mathrm{~A}-3-2,78 \mathrm{~cm}$. (b) Tubular, infilled trace fossil with dark colored outer rim, possibly a Rind burrow, in Oligocene nannofossil ooze, 352A-3-1, 105$120 \mathrm{~cm}$. (c) Irregular curvilinear trace fossil with intestino-form central filling, Oligocene mudstone, 345-14-4, $13 \mathrm{~cm}$. 
complete record of turbidite and glacial sedimentation from the Miocene or early Pliocene to the present is preserved. However, the sedimentary record is incomplete at ridge-top sites on the Iceland-Faeroe Plateau (336, 352, 352A); the extinct Norway Basin spreading ridge (337); V $\phi$ ring Plateau $(339,340,341$, 342 , and 343); Jan Mayen Ridge and its possible extension to the south $(346,347,348$, and 350$)$; and the Iceland Plateau (348). The sedimentary records at these sites provide information regarding the history of the particular ridge or plateau top, but not of the major sedimentary basins such as the Norway Basin, the Lofoten Basin, and the Greenland Basin (see Figure 1).

In addition, the lack of sites located in sedimentary basins west of the main spreading ridges prohibits a comparison of the relative influences on sedimentation of the bordering continental margins in the NorwegianGreenland Sea. Nevertheless, the rudimentary framework of the sedimentary history and evolution of the area can be roughly outlined from the available data.

The oldest and lowest sedimentary units, of preOligocene, Eocene, or Paleocene age, consist of sedimentary basalt breccias, of nonmarine origin at Sites 336 on the Iceland-Faeroe Plateau and 345 in the Lofoten Basin, and of probable marine origin at Site 350 south of Jan Mayen Ridge. Site 343 at the base of the seaward flank of the $\mathrm{V} \phi$ ring Plateau contains thin lower Eocene turbidites resting directly on basalt, whereas at Site 338 on the top of the V $\phi$ ring Plateau, lower Eocene terrigenous mudstone and sandy mudstone rests directly on basalt. However, above the terrigenous sediments are younger Eocene biogenic sediments, which were also found at Site 340 on the $\mathrm{V} \phi$ ring Plateau.

Above the nonmarine breccias at Site 345 , the key site for understanding the sedimentary development of the area, are lateritic paleosols and thin marine sandstones, conglomerates, and sandy mudstones of early Oligocene age that record a rapid transition from nonmarine to deep marine sedimentation. A thick turbidite sequence that in general thins and fines upward overlies these transitional sediments and is in turn overlain by Oligocene terrigenous mudstones, and subsequently by Miocene biogenic sediments and ice-rafted Plio-Pleistocene sediments. Thus, the vertical sequence at Site 345 fits the general model of rifted-margin ocean basin sedimentation elucidated earlier: sediments become less terrigenous and more biogenic upward through time, and sediments record a progressive deepening at individual sites through time.

This model can perhaps be visualized more clearly in Figures 26 and 27 , which diagrammatically show the stratigraphic development of sedimentary sequences in the Norwegian-Greenland Sea. Initial sedimentation in the rift system, when it developed on and within the originally joined Greenland and Norway-Spitsbergen continental blocks, consists of subaerially extruded and weathered Paleocene or Eocene basalts, overlain at least locally by lateritic paleosols. As spreading continues, the rift area widens and subsides rapidly, with the incursion of marine waters from the south, and deposition of transitional Eocene marine sediments and then thick relatively proximal turbidites in basinal areas. Pebbly mudstones deposited by debris flows, slumps, sediment gravity flows, syndepositional folding, and preconsolidation deformation mark this period of rapid opening and subsidence of the still narrow rift basin.

With continued spreading and widening of the ocean basin, newly formed Oligocene oceanic crust receives only distal fine-grained turbidites and then terrigenous to hemipelagic mudstones, derived mainly from the increasingly distant continental margins. By Miocene time, the continental margins are too far away to influence sedimentation on the newly formed crust, and biogenic sedimentation, either diatomaceous, spiculitic, or nannofossil-rich, becomes the dominant type of sedimentation. Sedimentation rates become increasingly slower as the continental margins are displaced increasingly greater distances from the newly created sites of ocean floor sedimentation. Finally, in the PlioPleistocene, extensive ice cover results in the deposition of ice-rafted material over the entire ocean floor and directly on basalt near the active spreading ridges. Near the continental margins, terrigenous sediments derived from the nearby continent and deposited by bottomflowing turbidity currents, floodwater overflows during interglacial periods, and other processes derived continue to accumulate; however, marginal sites in areas such as the eastern Lofoten Basin were not drilled, so we have little record of this continental margin sedimentation. However, some thin turbidites of "glacial" age are found at sites such as 344 near Spitsbergen and 341 on top of and 343 at the base of the $\checkmark \phi$ ring Plateau.

Intermixed sporadically through all of the sequences are volcanic ash layers, derived from various sources such as the adjacent continents (e.g., volcanic centers in Northern Soctland and eastern Greenland), individual oceanic volcanic islands standing above sea level (e.g., Jan Mayen Island), and the volcanic plateaus built up by voluminous outpourings of lava (e.g., Iceland, Iceland-Faeroe Plateau, and probably the V $\phi$ ring Plateau). The ash layers vary in composition, depending on the source, and are persistent but irregularly distributed components of the Norwegian-Greenland Sea sedimentary record.

The turbiditic Paleogene sedimentary sequences at Jan Mayen Ridge Sites (346, 347, 349, and 350) suggest that if the ridge originally was attached to the eastern Greenland continental margin, it formed part of the continental rise rather than part of the shelf or slope area. Alternatively, it may have formed a faultbounded marginal basin such as the inner V $\phi$ ring Plateau or Viking graben of the North Sea. It may thus be underlain by transitional crust rather than clearly continental or oceanic crust.

In summary, the complex spreading history and the juxtaposition of diversely oriented tectonic and volcanic features in the Norwegian-Greenland Sea yield a relatively complex pattern of Tertiary sedimentation. Although the sedimentary sequences are probably basically similar to late Mesozoic rift-margin basin deposits of the North Atlantic and South Atlantic oceans, there are several major differences: (1) 


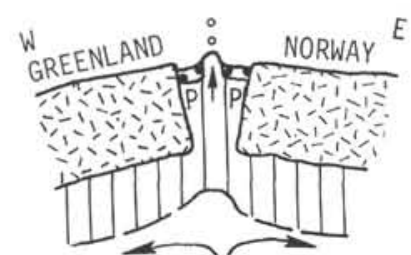

STAGE 1
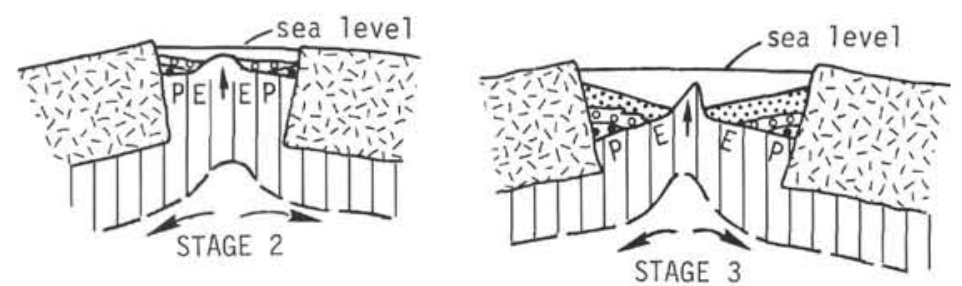
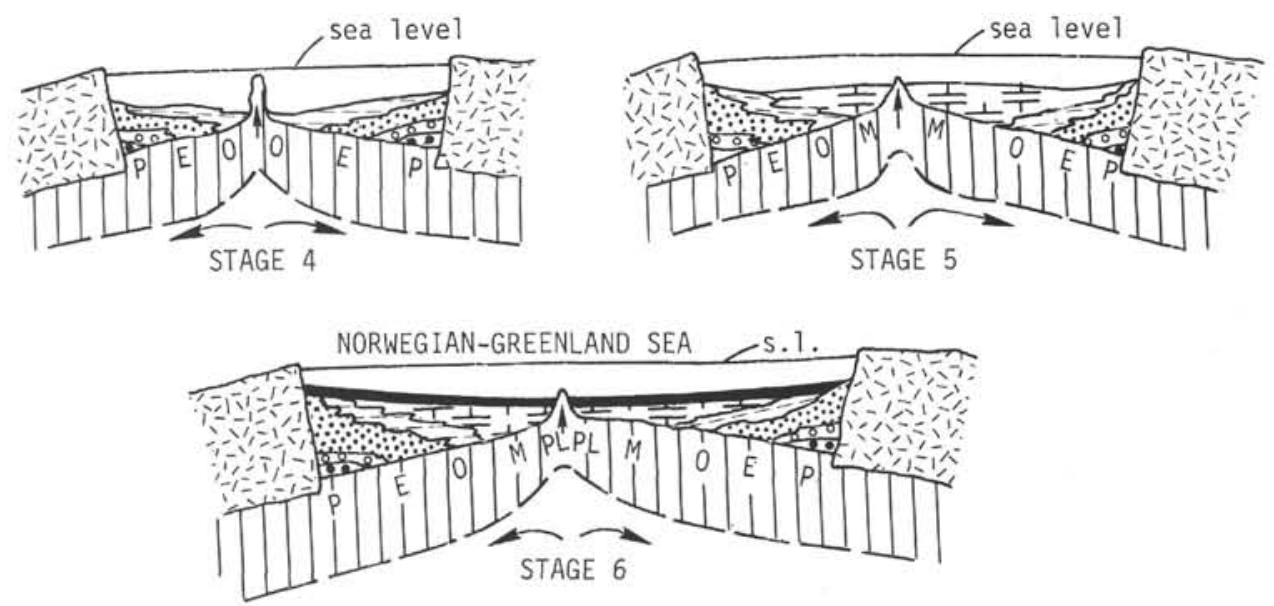

LITHOLOGIC SYMBOLS
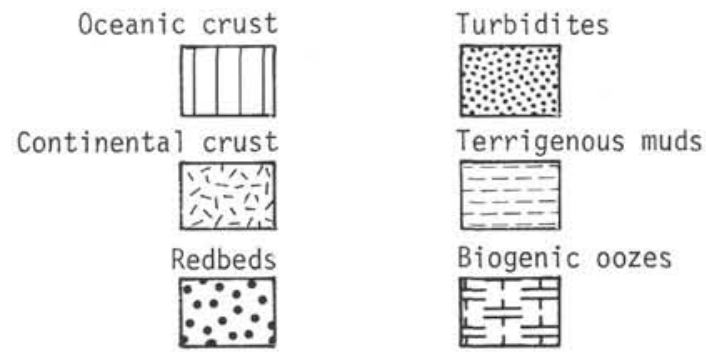

Transitional marine sediments
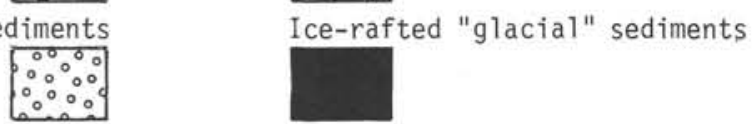

Figure 26. Diagrammatic sketches showing sequential development of Norwegian-Greenland Sea area and stratigraphic relationships. Stage 1, Paleocene, initial rifting, deposition of redbeds on subaerially weathered basalts. Stage 2, early Eocene, incursion of oceanic waters, subsidence, deposition of transitional marine sediments. State 3, late Eocene, deposition of turbidites. Stage 4, Oligocene, deposition of terrigenous mudstones in center of basin. Stage 5, Miocene deposition of biogenic oozes in center of basin. Stage 6, Plio-Pleistocene, deposition of blanket ot ice-rafted sediments. Symbols on oceanic crust indicate age of crust: P, Paleocene; E, Eocene; O, Oligocene; $M$, Miocene; P-PL, Plio-Pleistocene.

evaporites, which chracterize the early stages of rifting in the Atlantic further to the south, apparently did not form in the Norwegian-Greenland Sea area, either because climatic conditions were different, because the newly formed basin subsided very rapidly, or the basin was not rimmed by a sill controlling the inflow and outflow of water; (2) the Norwegian-Greenland Sea is much narrower, shallower, and the bordering continental areas are much higher than in the Atlantic Ocean, producing a basin more likely to be characterized by terrigenous than biogenic sedimentation; and (3) the position of the Norwegian-Greenland Sea in more northern latitudes resulted in widespread deposition of ice-rafted glacial sediments.

\section{ACKNOWLEDGMENTS}

I would like to acknowledge my shipboard colleagues, particularly the sedimentologists, for their assistance in catalog. ing and recording the distribution of the various structures and features reported herein, and the shipboard technicians 


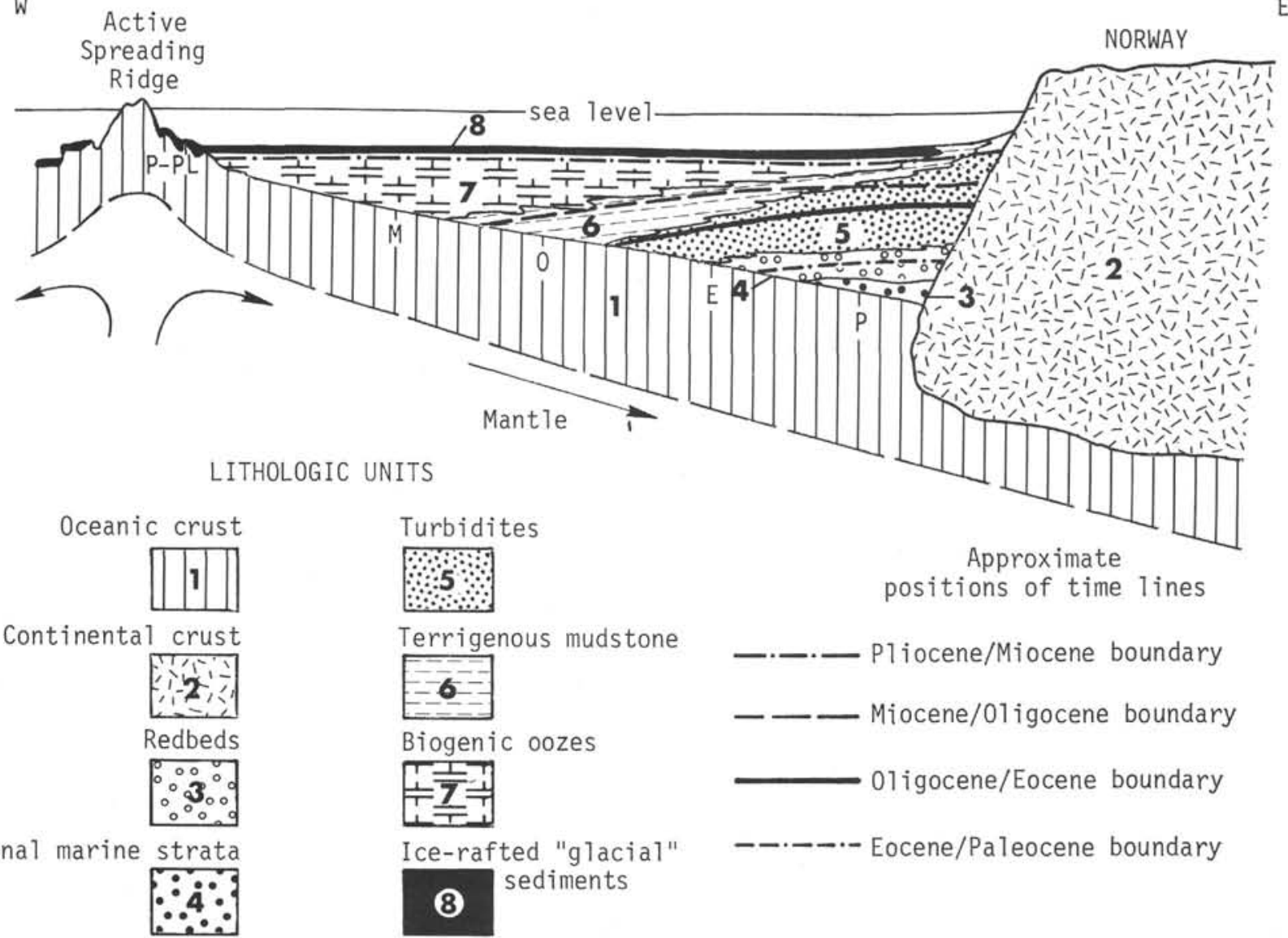

Figure 27. Diagrammatic stratigraphic cross-section of eastern Norwegian-Greenland Sea, showing time lines, distribution of sediment types, and idealized facies relations of lithostratigraphic units. Letters on oceanic crust indicate approximate ages of crust: P, Paleocene; E, Eocene; O, Oligocene; M, Miocene; P-PL, Plio-Pleistocene.

for assistance in sampling, photographing, and various other matters. Many of the photos were taken by Jan E. van Hinte, whom I thank for the virtually unlimited use of his photographic equipment and time. Dennis R. Kerr of the U.S. Geological Survey undertook most of the laboratory work on the redbed sequence of Site 336 and wrote most of that section. C. Kent Chamberlain of Ohio University kindly examined many photographs of trace fossils and made many helpful suggestions.

\section{REFERENCES}

Bouma, A.H., 1962. Sedimentology of some flysch deposits: Amsterdam (Elsevier Publ. Co.), 168 p.

Chamberlain, C.K., 1973. A manual for recognizing trace fossils in deep-sea cores: unpublished and unpaginated report for the Deep-Sea Drilling Project, December 1973.

Erkdale, A.A., 1974. Geological history of the abyssal benthos: evidnce from trace fossil in Deep Sea Drilling Project cores: Ph.D. Thesis, Rice Univ., 156 p.

Frey, R.W. (Ed.), 1975. The study of trace fossils: Berlin (Springer-Verlag), $562 \mathrm{p}$.

Frey, R.W. and Howard, J.D., 1970. Comparison of Upper Cretaceous ichnofaunas from siliceous sandstones and chalk, western interior region, U.S.A., In Crimes, T.P. and Harper, J.C. (Eds.), Trace fossils: Geol. J., Spec. Issue 3, p. 141-166.
Hantzschel, W., 1962. Trace fossils and problematica. In Moore, R.C., (Ed.), Treatise on invertebrate paleontology, Part W, Miscellanea: Kansas (Univ. Kansas Press), p. $177-245$.

Kennedy, W.J., 1970. Trace fossils in the chalk environment. In Crimes, T.P. and Harper, J.C. (Eds.), Trace fossils: Geol. J., Spec. Issue 3, p. 263-282.

Lowe, D.R. and LoPiccolo, R.D., 1974. The characteristics and origins of dish and pillar structures: J. Sediment Petrol., v. 44, p. 484-501.

Middleton, G.V. and Hampton, M.A., 1973. Sediment gravity flows-mechanics of flow and deposition. In Middleton, G.V., and Bouma, A.H. (Co-chm.), Turbidites and deepwater sedimentation: Lecture Notes for Short Cource, Pacific Sec., Soc. Econ. Paleontol. Mineral., p. 1-38.

Mutti, E. and Ricci Lucchi, F., 1972. Le torbiditi dell' Appenino settentrionale: introduzione all' analisi di facies: Soc. Ital. Geol. Mem. 11, p. 161-199.

Seilacher, A., 1967. Bathymetry of trace fossils: Marine Geol., v. 5 , p. $413-428$.

Simpson, S., 1967. On the trace fossil Chondrites: Quart. J. Geol. Soc. London, v. 112, p. 475-499.

Stauffer, P.H., 1967. Grain-flow deposits and their implications, Santa Ynez Mountains, California: J. Sediment Petrol., v. 37, p. 487-508.

van der Lingen, G.J., 1973. Ichnofossils in deep-sea cores from the southwest Pacific. In Burns, R.E., Andrews, J.E., et al., Initial Reports of the Deep Sea Drilling Project, 
Volume 21: Washington (U.S. Government Printing Office), p. 693-700.

Warme, J.E., Kennedy, W.J., and Schneidermann, N., 1973. Biogenic sedimentary structures (trace fossils) in Leg 15 cores. In Edgar, N.T., Saunders, J.B., et al., Initial Reports of the Deep Sea Drilling Project, Volume 15: Washington (U.S. Government Printing Office), p. 813-831.

Wentworth, C.M., 1967. Dish structure, a primary sedimentary structure in coarse turbidites (abs.): Am. Assoc. Petrol. Geol., v. 51, p. 485.

Wilson, H.E., 1972. Regional geology of Northern Ireland: Geological Survey of Northern Ireland, Belfast: London (Her Majesty's Stationary Office), 115 p.

\section{ADDITIONAL SELECTED REFERENCES}

Berger, W.H. and Heath, G.R., 1968. Vertical mixing in pelagic sediments: J. Marine Res., v. 26, p. 134-143.

Berger, W.H. and von Rad, U., 1972. Cretaceous and Cenozoic sediments from the Atlantic Ocean. In Hayes, D.E., Pimm, A.C., et al., Initial Reports of the Deep Sea Drilling Project, Volume 14: Washington (U.S. Government Printing Office), p. 787-954.

Bouma, A.H. and Brouwer, A. (Eds.), 1964. Turbidites: Amsterdam (Elsevier Publ. Co.), 264 p.

Bourne, D.W. and Heezen, B.C., 1965. A wandering Enteropneust from the abyssal Pacific and the distribution of "spiral" tracks on the sea floor: Science, v. 150, p. 6063.

Clarke, R.H., 1968. Burrow frequency in abyssal sediments: Deep-Sea Res., v. 15 , p. 397-400.

Crimes, T.P. and Harper, J.C. (Eds.), 1970. Trace fossils: Geol. J., Spec. Issue 3, 547 p.

Donahue, J., 1971. Burrow morphologies in north-central Pacific sediments: Marine Geol., v. 11, p. M1-M7.

Dzulynski, S. and Walton, E.K., 1965. Sedimentary features of flysch and graywackes: Amsterdam (Elsevier Publ. Co.), 274 p.

Ericson, D.B., Ewing, M., Wallin, G., and Heezen, B.C., 1961. Atlantic deep-sea cores: Geol. Soc. Am. Bull., v. 72, p. $139-286$.

Griggs, G.B., Carey, A.G., Jr., and Kulm, L.D., 1969. Deepsea sedimentation and sediment-fauna interaction in Cascadia channel and on Cascadia abyssal plain: DeepSea Res., v. 16, p. 157-170.

Gubler, J., Bugnicourt, D., Faber, J., Kurler, B., and Nyssen, R., 1966. Essai de nomenclature et caracterisation des principales structures sedimentaires: Paris (Editions Technip), $291 \mathrm{p}$.

Hanor, J.S. and Marshall, N.F., 1971. Mixing of sediment by organisms, In Perkins, B.F., (Ed.), Trace fossils, a field guide: Louisiana State University, School Geosci., Misc. Publ. 71-1, p. 127-135.

Hantzschel, W., 1975. Trace fossils and Problematica, in Treatise on invertebrate paleontology, Supplement 1, Part W, 2nd ed.: Kansas (Univ. Kansas Press).

Heezen, B.C. and Hollister, C.D., 1971. The face of the deep: New York (Oxford University Press), 659 p.

Hollister, C.D., Heezen, B.C., and Nafe, K.E., 1975. Animal traces on the deep-sea floor. In Frey, R.W., (Ed.), The study of trace fossils: New York (Springer-Verlag), p. 493510.

Maignlen, R., 1966. Review of research on laterites: Paris, UNESCO, 148 p.

Maurrasse, F., 1973. Sedimentary structures of Caribbean Leg 15 sediments. In Edgar, N.T., Saunders, J.B., et al., Initial Reports of the Deep Sea Drilling Project, Volume 15: Washington (U.S. Government Printing Office), p. 833-845.

Pettijohn, F.J. and Potter, P.E., 1964. Atlas and glossary of primary sedimentary structures: Berlin (Springer-Verlag), $370 \mathrm{p}$.

Pimm, A.C., Garrison, R.E., and Boyce, R.E., 1971. Sedimentology synthesis-lithology, chemistry, and physical properties of sediments in the northwestern Pacific Ocean. In Fischer A.G., Heezen, B.C. et al., Initial Reports of the Deep-Sea Drilling Project, Volume 6: Washington (U.S. Government Printing Office), p. 11311252.

Piper, D.J.W. and Marshall, N.F., 1969. Bioturbation of Holocene sediments on La Jolla Deep Sea Fan, California: J. Sediment. Petrol., v. 39, p. 601-606.

Piper, D.J.W. and Schrader, H.J., 1973. Bioturbation of sediments. In Kulm, L.D., von Huene, R., et al., Initial Reports of the Deep Sea Drilling Project, Volume 18: Washington (U.S. Government Printing Office), p. 869 875.

Sokolova, M.N., 1959. On the distribution of deep-water bottom animals in relation to their feeding habits and the character of sedimentation: Deep-Sea Res., v. 6, p. 1-4.

Van Houten, F.B., 1968. Iron oxides in red beds: Geol. Soc. Am. Bull., v. 79, p. 399-416.

, 1973. Origin of red beds, a review-1961-1972:

Earth Planet. Sci. Ann. Rev., v. 1, p. 39-61. 